\title{
Identification of Multiple Pancreatic and Extra-Pancreatic Pathways Underlying the Glucose-Lowering Actions of Acacia arabica Bark in Type-2 Diabetes and Isolation of Active Phytoconstituents
}

\author{
Prawej Ansari ${ }^{1,2, *(\mathbb{D})}$, Peter R. Flatt ${ }^{1}{ }^{(}$, Patrick Harriott ${ }^{1}$, J. M. A. Hannan ${ }^{2}$ and Yasser H. A. Abdel-Wahab ${ }^{1}(\mathbb{D}$ \\ 1 School of Biomedical Sciences, Ulster University, Coleraine BT52 1SA, UK; pr.flatt@ulster.ac.uk (P.R.F.); \\ p.harriott@ulster.ac.uk (P.H.); y.abdel-wahab@ulster.ac.uk (Y.H.A.A.-W.) \\ 2 Department of Pharmacy, Independent University, Dhaka 1229, Bangladesh; jmahannan@iub.edu.bd \\ * Correspondence: pr.ansari@iub.edu.bd; Tel.: +88-0-1323879720
}

Citation: Ansari, P.; Flatt, P.R.; Harriott, P.; Hannan, J.M.A.; Abdel-Wahab, Y.H.A. Identification of Multiple Pancreatic and Extra-Pancreatic Pathways Underlying the Glucose-Lowering Actions of Acacia arabica Bark in Type-2 Diabetes and Isolation of Active Phytoconstituents. Plants 2021, 10, 1190. https://doi.org/10.3390/ plants10061190

Academic Editor: Ki Hyun Kim

Received: 10 May 2021

Accepted: 9 June 2021

Published: 11 June 2021

Publisher's Note: MDPI stays neutral with regard to jurisdictional claims in published maps and institutional affiliations.

Copyright: (c) 2021 by the authors. Licensee MDPI, Basel, Switzerland. This article is an open access article distributed under the terms and conditions of the Creative Commons Attribution (CC BY) license (https:// creativecommons.org/licenses/by/ $4.0 /)$.

\begin{abstract}
Acacia arabica is used traditionally to treat a variety of ailments, including diabetes. This study elucidated the antidiabetic actions of $A$. arabica bark together with the isolation of bioactive molecules. Insulin secretion and signal transduction were measured using clonal $\beta$ cells and mouse islets. Glucose uptake was assessed using 3T3-L1 adipocytes, and in vitro systems assessed additional glucose-lowering actions. High-fat-fed (HFF) obese rats were used for in vivo evaluation, and phytoconstituents were isolated and characterised by RP-HPLC followed by LC-MS and NMR Hot-water extract of $A$. arabica (HWAA) increased insulin release from clonal $\beta$ cells and mouse islets by 1.3-6.8-fold and 1.6-3.2-fold, respectively. Diazoxide, verapamil and calcium-free conditions decreased insulin-secretory activity by $30-42 \%$. In contrast, isobutylmethylxanthine (IBMX), tolbutamide and $30 \mathrm{mM} \mathrm{KCl}$ potentiated the insulin-secretory effects. The mechanism of actions of HWAA involved membrane depolarisation and elevation of intracellular $\mathrm{Ca}^{2+}$ together with an increase in glucose uptake by 3T3-L1 adipocytes, inhibition of starch digestion, glucose diffusion, dipeptidyl peptidase-IV (DPP-IV) enzyme activity and protein glycation. Acute HWAA administration (250 mg $/ 5 \mathrm{~mL} / \mathrm{kg}$ ) enhanced glucose tolerance and plasma insulin in HFF obese rats. Administration of HWAA ( $250 \mathrm{mg} / 5 \mathrm{~mL} / \mathrm{kg}$ ) for 9 days improved glucose homeostasis and $\beta$-cell functions, thereby improving glycaemic control, and circulating insulin. Isolated phytoconstituents, including quercetin and kaempferol, increased insulin secretion in vitro and improved glucose tolerance. The results indicate that HWAA has the potential to treat type 2 diabetes as a dietary supplement or as a source of antidiabetic agents, including quercetin and kaempferol.
\end{abstract}

Keywords: glucose; insulin; obesity; diabetes; DPP-IV; islets; beta cells; phytochemistry

\section{Introduction}

Diabetes mellitus (DM) is one of the fastest-growing metabolic disorders resulting from deficiency of insulin, disturbed beta-cell function or insulin resistance [1]. Type 1 diabetes mellitus (T1DM) typically develops under the age of 30, when beta cells are destroyed. Type 2 diabetes mellitus (T2DM) is commonly found over the age of 40, but it is increasingly common in children and young adults due to childhood obesity, which causes beta-cell dysfunction and insulin resistance. Both major forms of diabetes are characterised by hyperglycaemia, which is a major player in the risk of developing diabetic complications such as cardiovascular disease, neuropathy, retinopathy and nephropathy [2]. Diet, weight loss and the use of single or multiple oral antidiabetic drugs are prevalent treatment options for T2DM. Such agents, including DPP-IV inhibitors and glucagon-like peptide-1 mimetics, are being used to improve glucose tolerance via the potentiation of glucose-stimulated insulin secretion [2,3]. GIP and GLP-1, two incretin hormones secreted from intestinal K 
and $L$ cells after a meal, are very effective regulators of postprandial hyperglycaemia [4]. The DPP-IV enzyme dictates the half-life of incretin hormones by cleaving the first two $\mathrm{N}$-terminal amino acids to generate inactive forms, namely GIP (3-42) and GLP-1 (9-36) [5]. DPP-IV inhibitors are therefore useful for treating type 2 diabetes by reducing DPP-IV enzyme activity and increasing circulating concentrations of the active forms of both hormones. The advent of medical advances in treatment options has resulted in better glycaemic control. However, these options are often expensive and have secondary side effects that sometimes limit their use in wider and particularly poorer sections of society.

Herbal medicines are popular for a wide variety of ailments, and according to WHO, $75 \%$ of the global population uses herbs for basic healthcare needs [6]. Several medicinal plants and their formulations have gained attention in diabetes treatment [7]. An ethnobotanical and pharmacological survey provided useful information on plant species reported to possess antidiabetic activity that could be used as an adjunct treatment for T2DM therapy $[8,9]$. Folk medicines are popular and apparently effective for diabetes treatment in many regions of the world because of their availability, low cost and apparent safety and effectiveness [10]. However, few have been subjected to scientific scrutiny, and the mechanisms of action and nature of the active constituents are unknown. Several plants, including Trigonella foenum greacum, have been reported many times for their ability to treat T2DM [11,12]. Moreover, nearly 200 isolated compounds from different plant sources have been reported to lower blood glucose [9]. Some of these are alkaloids, carbohydrates, glycosides, flavonoids, steroids, terpenoids, peptides and amino acids, lipids, phenolic, glycopeptides and iridoids.

The gum of Acacia arabica is traditionally known as "Samghe arabi" in Persian medicine. The fruits have a long background of traditional use as an astringent, a diuretic, an antimicrobial and in wound healing therapy, as well as a liver tonic [13]. The gum is actively used as a dietary supplement for diabetes treatment in Ayurvedic medicine [14]. A previous study reported that fruits of $A$. arabica had no significant hypoglycaemic action in diabetic rabbits but lowered blood glucose in normal animals [15]. Several parts of $A$. arabica have been studied for hypoglycaemic effects [16-18]. A recent study also reported the potential effect of $A$. arabica on insulin resistance, blood glucose and lipid profile in streptozotocin (STZ)-induced diabetic rats [19]. None of these studies has provided a convincing and full account of the antidiabetic activity of $A$. arabica. Therefore, the present study was designed to fully investigate the pancreatic and extrapancreatic antidiabetic properties of $A$. arabica in vitro and in vivo to understand the mechanisms of action and nature of its bioactive compounds.

\section{Results}

\subsection{Effects of Extract of A. arabica Bark on Insulin Release from BRIN-BD11 Cells}

The basal rate of insulin release from BRIN-BD11 cells in the presence of $5.6 \mathrm{mM}$ glucose was $0.87 \pm 0.03 \mathrm{ng} / 10^{6}$ cells $/ 20 \mathrm{~min}$, and this rate increased to $4.45 \pm 0.53 \mathrm{ng} / 10^{6}$ cells $/ 20 \mathrm{~min}(p<0.05 ; n=8)$ in the presence of alanine $(10 \mathrm{mM})$ (Figure $1 \mathrm{~A})$. At $16.7 \mathrm{mM}$ glucose, basal insulin release was $1.50 \pm 0.07 \mathrm{ng} / 106$ cells $/ 20 \mathrm{~min}$, which was increased to $8.40 \pm 0.44 \mathrm{ng} / 106$ cells $/ 20 \mathrm{~min}$ in the presence of $30 \mathrm{mM} \mathrm{KCl}$ (Figure 1B). Hot-water extract of $A$. arabica bark stimulated insulin release in a dose-dependent manner $(1.6-5000 \mu \mathrm{g} / \mathrm{mL})$ at $5.6 \mathrm{mM}$ or $16.7 \mathrm{mM}$ glucose $(p<0.05-0.001$; Figure $1 \mathrm{~A}, \mathrm{~B})$. Extract at $5000 \mu \mathrm{g} / \mathrm{mL}$ produced maximum responses of 5.1- to 6.8-fold times the basal rate. However, the higher concentrations $(200,1000$ and $5000 \mathrm{ug} / \mathrm{mL}$ ) increased lactate dehydrogenase (LDH) release by 1.30-6.18-fold (Figure S1A,B). At extract concentrations of $1.6-40 \mu \mathrm{g} / \mathrm{mL}$, no lactate dehydrogenase ( $\mathrm{LDH}$; cytosolic enzyme) release was observed, indicating the lack of deleterious effects on plasma membrane (Figure S1A,B). 

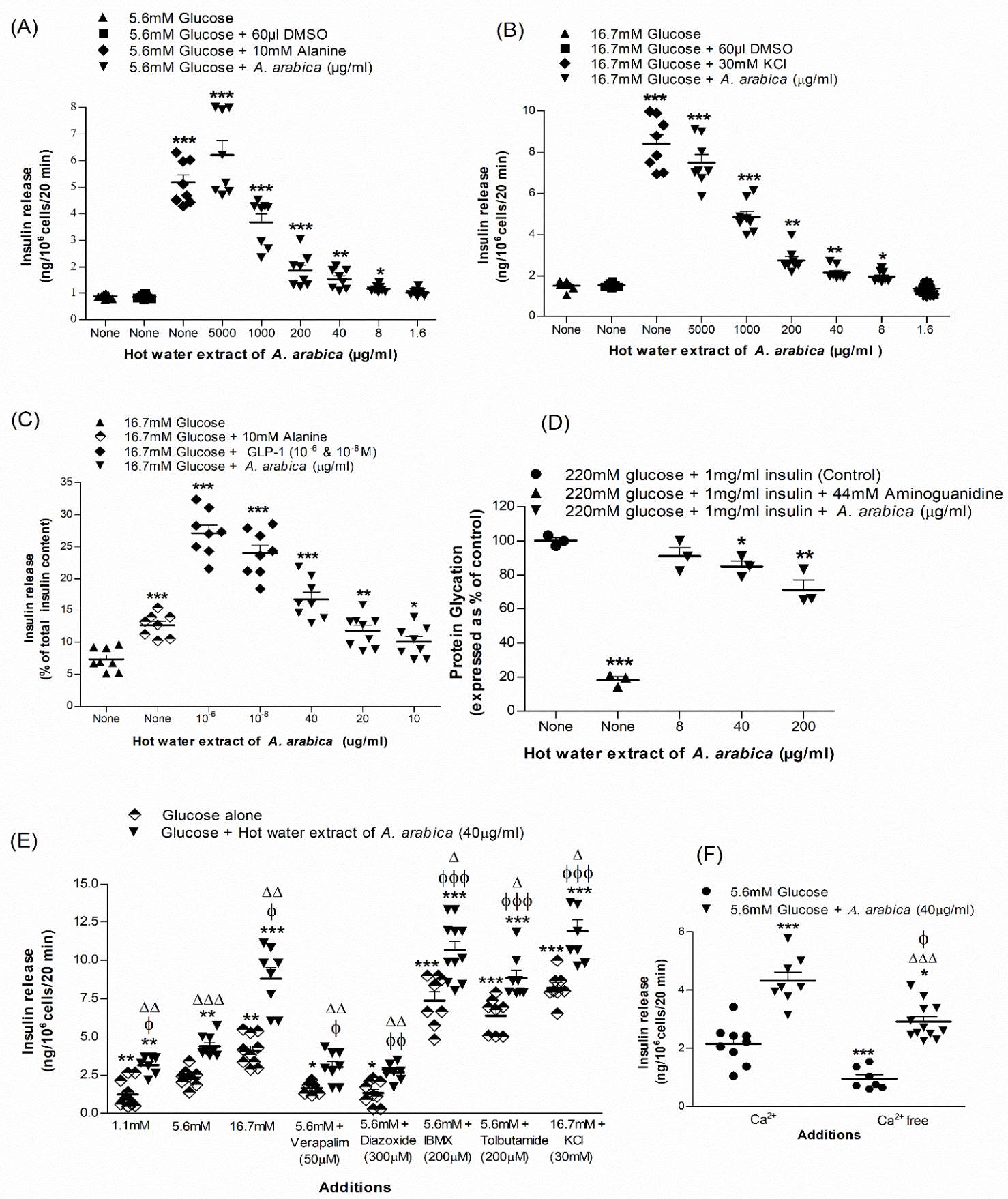

Figure 1. Dose-dependent effects of hot-water extract of A. arabica bark on insulin release from (A,B) BRIN-BD11 cells and (C) islets of Langerhans, (D) protein glycation, (E) insulin secretion in the presence of established stimulators or inhibitors and (F) absence of extracellular calcium. Values are the mean \pm SEM for $n=4-8$ for insulin release and $n=3$ for protein glycation. ${ }^{*} p<0.05,{ }^{* *} p<0.01$ and ${ }^{* * *} p<0.001$ compared to control (5.6/16.7 mM glucose and $220 \mathrm{mM}$ glucose + insulin $(1 \mathrm{mg} / \mathrm{mL})) .{ }^{\phi} p<0.05, \phi \Phi p<0.01$ and $\phi \phi \phi p<0.001$ compared to $5.6 \mathrm{mM}$ glucose in the presence of the extract. ${ }^{\Delta} p<0.05$, $\Delta \Delta p<0.01$ and ${ }^{\Delta \Delta \Delta} p<0.001$ compared to respective incubation in the absence of the extract.

\subsection{Effects of Extract of A. arabica Bark on Insulin Release from Isolated Mouse Islets}

Hot-water extract produced a substantial increase in insulin secretion from isolated mouse islets at $16.7 \mathrm{mM}$ glucose (Figure 1C). A significant stimulation was produced at extract concentrations of $\geq 20 \mu \mathrm{g} / \mathrm{mL}$ (Figure 1C). The increase in insulin secretion induced by hot-water extract was moderately less than the positive control GLP- $1\left(10^{-6}\right.$ and $\left.10^{-8} \mathrm{M}\right)$ in the presence of $16.7 \mathrm{mM}$ glucose (Figure $1 \mathrm{C}$ ). 


\subsection{Effects of Extract of A. arabica Bark on Glycation of Insulin}

Hot-water extract evoked a 15-30\% inhibition $(p<0.05-0.001$; Figure 1D) of insulin glycation at $40-200 \mu \mathrm{g} / \mathrm{mL}$. Aminoguanidine $(44 \mathrm{mM})$ used as positive control inhibited glycation by $83 \%(p<0.001$; Figure 1D).

\subsection{Insulinotropic Effects of Extract of A. arabica Bark in the Presence of Known Modulators of Insulin Release}

A. arabica $(40 \mu \mathrm{g} / \mathrm{mL})$ extract was incubated with known modulators of insulin release to evaluate mechanisms responsible for the insulinotropic activity of the plant (Figure 1E). Insulin-releasing effects were partly reduced by the $\mathrm{K}^{+}$channel activator, diazoxide $(300 \mu \mathrm{M})$. Similar inhibition was observed in the presence of the L-type voltagedependent $\mathrm{Ca}^{2+}$ channels blocker, verapamil $(50 \mu \mathrm{M})$ (Figure 1E). The insulin-releasing action was preserved in incubations with tolbutamide and a $30 \mathrm{mM}$ depolarising concentration of $\mathrm{KCl}$ (Figure 1E). The phosphodiesterase inhibitor, isobutylmethylxanthine (IBMX), also enhanced insulin-releasing activity $(p<0.001$; Figure 1E). Dependency of the plant's insulinotropic effect on $\left[\mathrm{Ca}^{2+}\right]$ i was confirmed by incubations in the absence of $\mathrm{Ca}^{2+}$, which diminished insulin release by $32 \%$ (Figure $1 \mathrm{~F}$ ).

\subsection{Effects of Extract of A. arabica Bark on Membrane Depolarisation and Intracellular Calcium Concentration in BRIN-BD11 Cells}

$\mathrm{KCl}(30 \mathrm{mM})$ and alanine $(10 \mathrm{mM})$ were used as positive controls that elicited significant depolarisation of membrane potential and elevation of $\left[\mathrm{Ca}^{2+}\right]$ i concentration, respectively $(p<0.001$; Figure 2A,B). Hot-water extract also evoked membrane depolarisation and an increase in $\left[\mathrm{Ca}^{2+}\right]$ i concentration $(p<0.001$; Figure 2A,B).

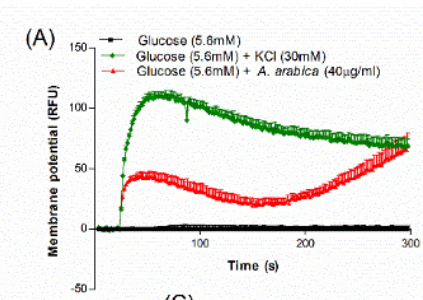

(C)

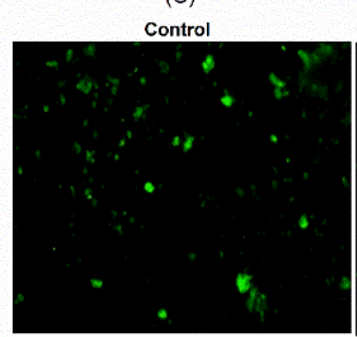

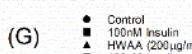

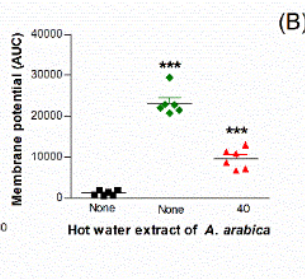

(D)
(B)

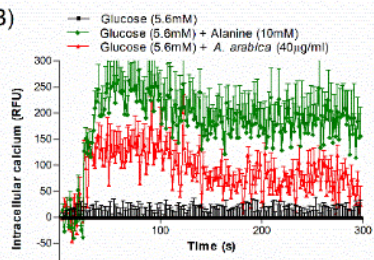

(E)

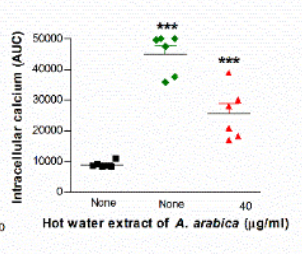

(F)

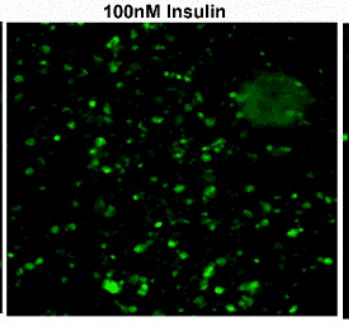

HWAA $(200 \mu \mathrm{g} / \mathrm{ml})$

HWAA $(200 \mu \mathrm{g} / \mathrm{ml})+100 \mathrm{nM}$ Insulin
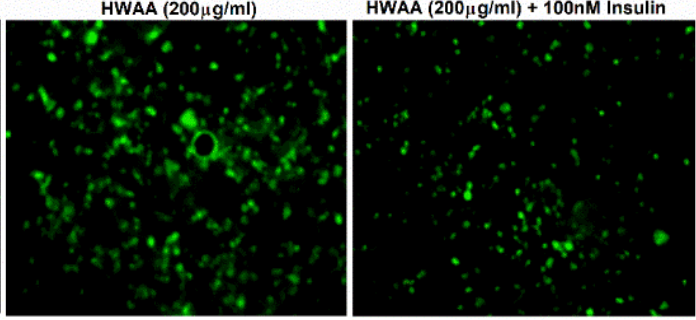

(H) ${ }_{1207}$ :
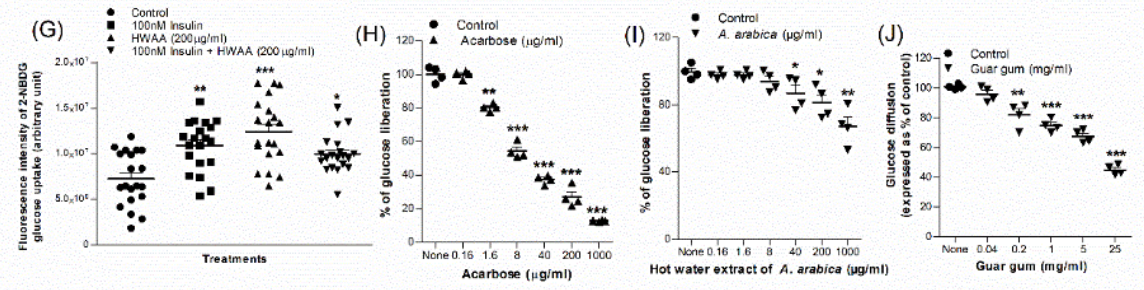

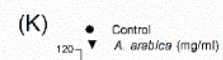

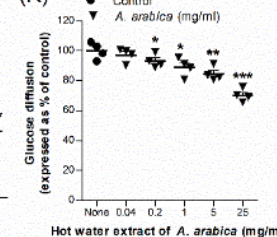

Figure 2. Effects of hot-water extract of A. arabica bark on (A) membrane potential and (B) intracellular calcium in BRIN BD11 cells, (C-G) glucose uptake in differentiated 3T3L1 adipocyte cells, (H) acarbose, (I) starch digestion, (J) guar gum and (K) glucose diffusion in vitro. Changes in fluorescence intensity in differentiated 3T3L1 adipocytes incubated with extract in the $(\mathbf{E})$ absence or $(\mathbf{F})$ presence of $100 \mathrm{nM}$ insulin. Images were taken at $10 \times$ magnification. Values are the mean \pm SEM for $n=6$ for membrane potential and intracellular calcium and $n=4(\sim 20$ values of fluorescence intensity per group for glucose uptake) for glucose uptake, starch digestion and glucose diffusion. ${ }^{*} p<0.05,{ }^{* *} p<0.01$ and ${ }^{* * *} p<0.001$ compared to control. 


\subsection{Effects of Extract of A. arabica Bark on Glucose Uptake and Insulin Action}

Glucose uptake and insulin action were studied using 3T3L1 differentiated adipocyte cells and a fluorescent glucose analogue (Figure 2C-G). In the microscopic fluorescence analysis, A. arabica extract enhanced glucose uptake significantly compared to control $(p<0.05-0.001$; Figure 2G). The effect was not potentiated by $100 \mathrm{nM}$ insulin. Insulin alone stimulated glucose uptake by 1.5 -fold $(p<0.01$; Figure 1G) compared to control.

\subsection{Effects of Extract of A. arabica Bark on Starch Digestion}

Acarbose $(1 \mathrm{mg} / \mathrm{mL})$ used as positive control inhibited enzymatic glucose liberation from starch by $87 \%$ (Figure $2 \mathrm{H}$ ). The hot-water extract significantly inhibited starch digestion at concentrations of $40-1000 \mu \mathrm{g} / \mathrm{mL}$, with a maximum of $32 \%$ inhibition $(p<0.01)$ at $1000 \mu \mathrm{g} / \mathrm{mL}$ (Figure 2I).

\subsection{Effects of Extract of A. arabica Bark on Glucose Diffusion In Vitro}

Hot-water extract of $A$. arabica $(\mathrm{mg} / \mathrm{mL})$ had significant inhibitory effects on glucose diffusion after $24 \mathrm{~h}$ of incubation (Figure $2 \mathrm{~K}$ ). The maximal inhibition of $30 \%$ was observed at $25 \mathrm{mg} / \mathrm{mL}(p<0.05-0.01$; Figure $2 \mathrm{~K})$. Guar gum $(25 \mathrm{mg} / \mathrm{mL})$ used as positive control inhibited glucose movement by a maximum of $55 \%$ (Figure 2J).

\subsection{Effects of Extract of A. arabica Bark on DPP-IV Enzyme Activity In Vitro}

Sitagliptin, an established drug $(10 \mu \mathrm{M})$, inhibited the enzymatic AMC liberation from the DPP-IV substrate, Gly-Pro-AMC, by $98 \%$ (Figure 3A). Hot-water extract significantly inhibited the DPP-IV enzyme by $18-93 \%(p<0.01-0.001$, Figure 3B) at $40-5000 \mu \mathrm{g} / \mathrm{mL}$.
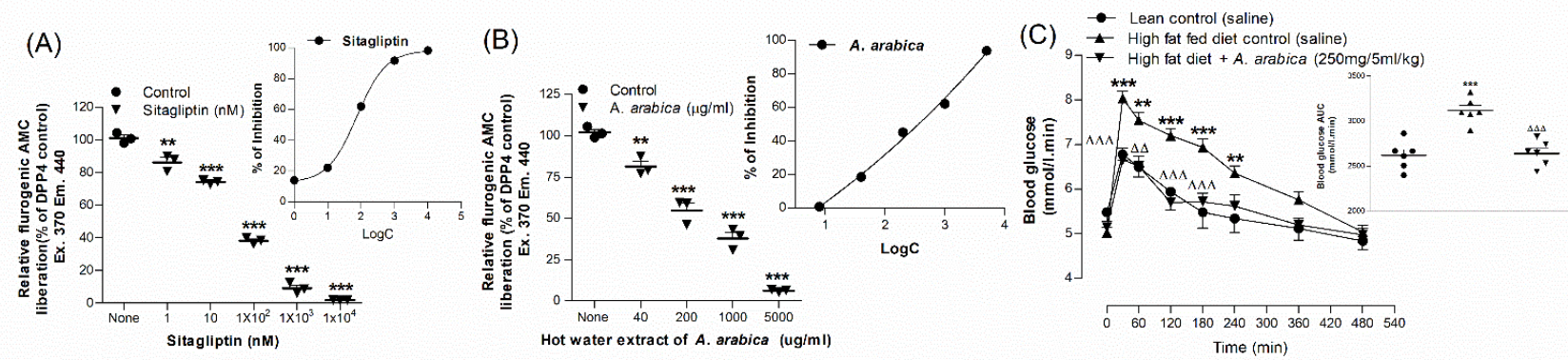

(D)
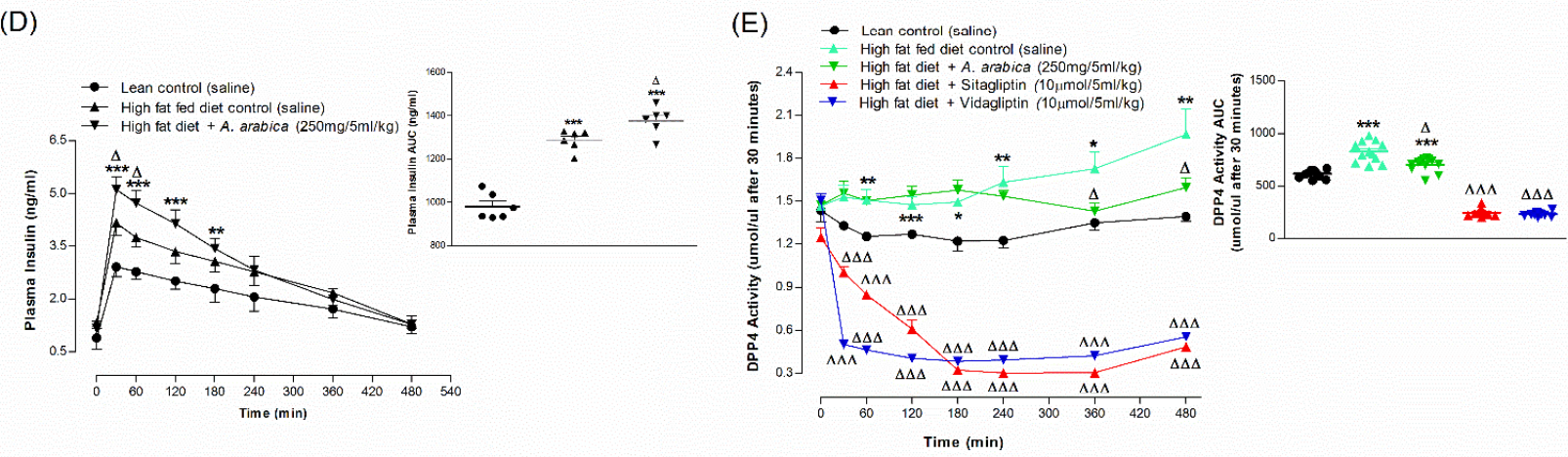

Figure 3. Acute effects of (A) sitagliptin and (B) hot-water extract of A. arabica bark on DPP-IV enzyme activity in vitro, (C) glucose tolerance, (D) plasma insulin and (E) plasma DPP-IV in high-fat-fed rats. Parameters were measured prior to and after oral administration of glucose alone ( $18 \mathrm{mmol} / \mathrm{kg}$ body weight, control) or with simultaneous $A$. arabica extract ( $250 \mathrm{mg} / 5 \mathrm{~mL} / \mathrm{kg}$ body weight). Established DPP-IV inhibitors, sitagliptin and vildagliptin, were used as positive controls. Values are the mean $\pm \mathrm{SEM}, n=3$ for DPP-IV enzyme activity in vitro and $n=6$ for glucose tolerance, plasma insulin and DPP-IV in vivo. ${ }^{*} p<0.05,{ }^{* *} p<0.01$ and ${ }^{* *} p<0.001$, compared to normal control and ${ }^{\Delta} p<0.05,{ }^{\Delta \Delta} p<0.01$ and $\Delta \Delta \Delta p<0.001$ compared to high-fat-fed control. 
2.10. Acute Effects of Hot-Water Extract of A. arabica Bark on Oral Glucose Tolerance and Plasma DPP-IV in High-Fat-Fed Rats

A single dose of $A$. arabica hot-water extract $(250 \mathrm{mg} / 5 \mathrm{~mL} / \mathrm{kg}$; body weight) elicited a significant $(p<0.05-0.001)$ decrease in blood glucose at 30, 60, 120 and 180 min compared to control rats (Figure 3C). The extract also significantly increased plasma insulin at 30 and $60 \mathrm{~min}(p<0.05$; Figure 3D). AUC analysis revealed a 13\% decrease $(p<0.001$; Figure $3 \mathrm{C})$ in blood glucose excursion and a 10\% increase $(p<0.05$; Figure 3D) in plasma insulin. The extract also inhibited plasma DPP-IV enzyme activity $(p<0.05)$ in a time-dependent manner (Figure 3E). AUC calculations also revealed an 11\% decrease in DPP-IV enzyme activity $(p<0.05$; Figure 3E). Sitagliptin and vildagliptin $(10 \mu \mathrm{mol} / 5 \mathrm{~mL} / \mathrm{kg})$, used as gold-standard drugs, produced $70-75 \%$ reductions in plasma DPP-IV enzyme activity $(p<0.001$; Figure 3E).

\subsection{Effects of Twice-Daily Oral Administration of Hot-Water Extract of A. arabica Bark on Body Weight and Metabolism in High-Fat-Fed Rats}

The treatment for 9 days with $A$. arabica extract $(250 \mathrm{mg} / 5 \mathrm{~mL} / \mathrm{kg}$; b.w.) resulted in significant improvements in all parameters measured (Figures $4 \mathrm{~A}-\mathrm{C}, \mathrm{E}, \mathrm{F}$ and $5 \mathrm{D}, \mathrm{E})$. Body weight and cumulative food intake were decreased by $9-12 \%(p<0.05-0.01$; Figure $4 \mathrm{~A}, \mathrm{D})$. The extract also reduced fluid intake and blood glucose by $9-14 \%(p<0.05-0.001$; Figures $4 \mathrm{C}, \mathrm{E}$ and 5D), with a clear-cut effect from 6 days onwards. The extract also increased plasma insulin by $14 \%(p<0.01$; Figures $4 \mathrm{~F}$ and $5 \mathrm{E})$ and inhibited DPP-IV enzyme activity from Day 6 onwards $(p<0.01$, Figures $4 \mathrm{G}$ and $5 \mathrm{~F})$.
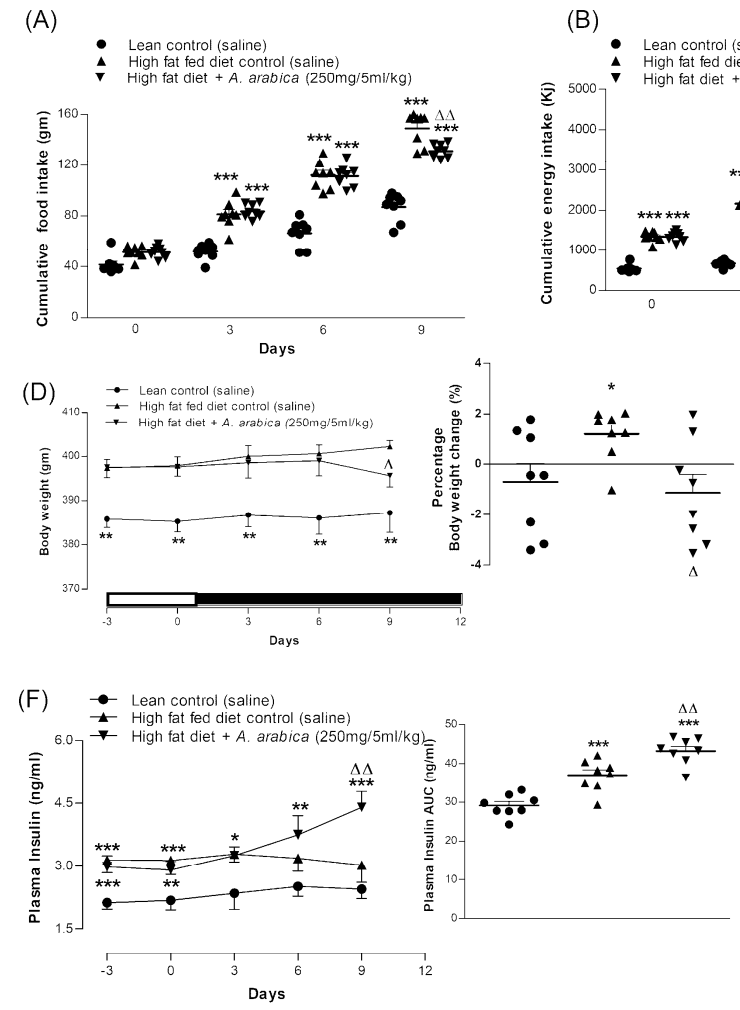
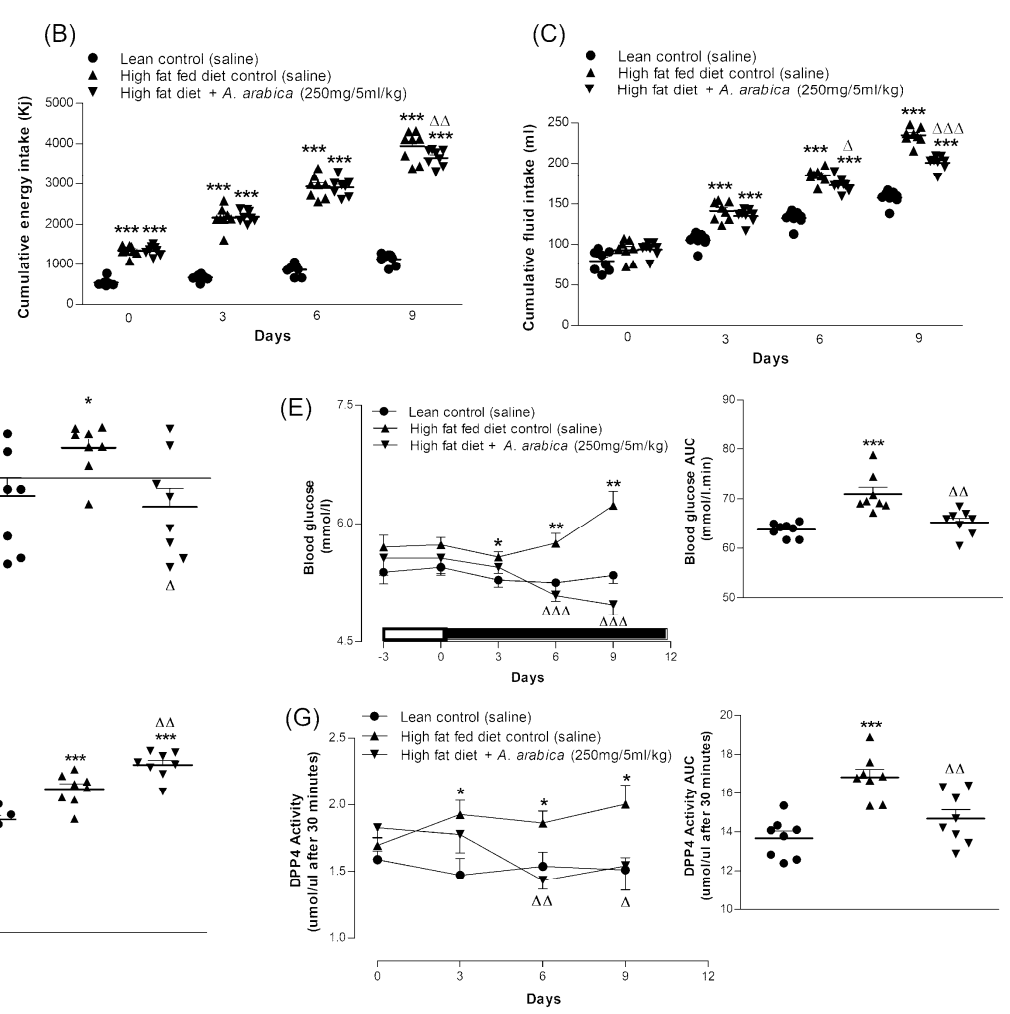

Figure 4. Effects of 9-day, twice-daily oral administration of hot-water extract of A. arabica bark on (A) food intake, (B) energy intake, (C) fluid intake, (D) body weight, (E) blood glucose, (F) plasma insulin and (G) DPP-IV enzyme activity in high-fat-fed rats. Parameters were measured prior to and after oral administration of A. arabica bark $(250 \mathrm{mg} / 5 \mathrm{~mL} / \mathrm{kg}$, body weight) twice daily. Values are the mean \pm SEM for $n=8$ rats. ${ }^{*} p<0.05,{ }^{* *} p<0.01$ and ${ }^{* * *} p<0.001$ compared to lean control. ${ }^{\Delta} p<0.05,{ }^{\Delta \Delta} p<0.01$ and ${ }^{\Delta \Delta \Delta} p<0.001$ compared to high-fat-fed control at corresponding time points. 
(A)

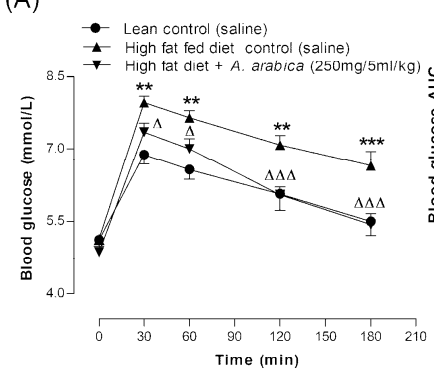

(C)
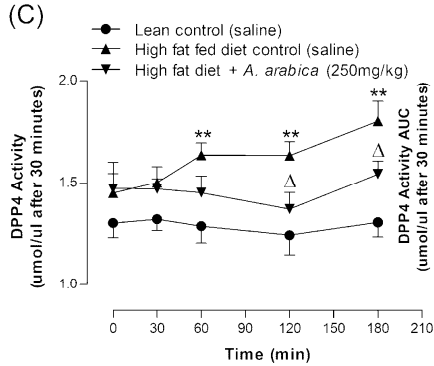

(F) - Lean control (saline)

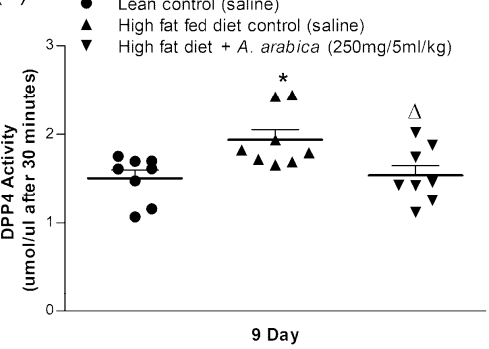

(B)
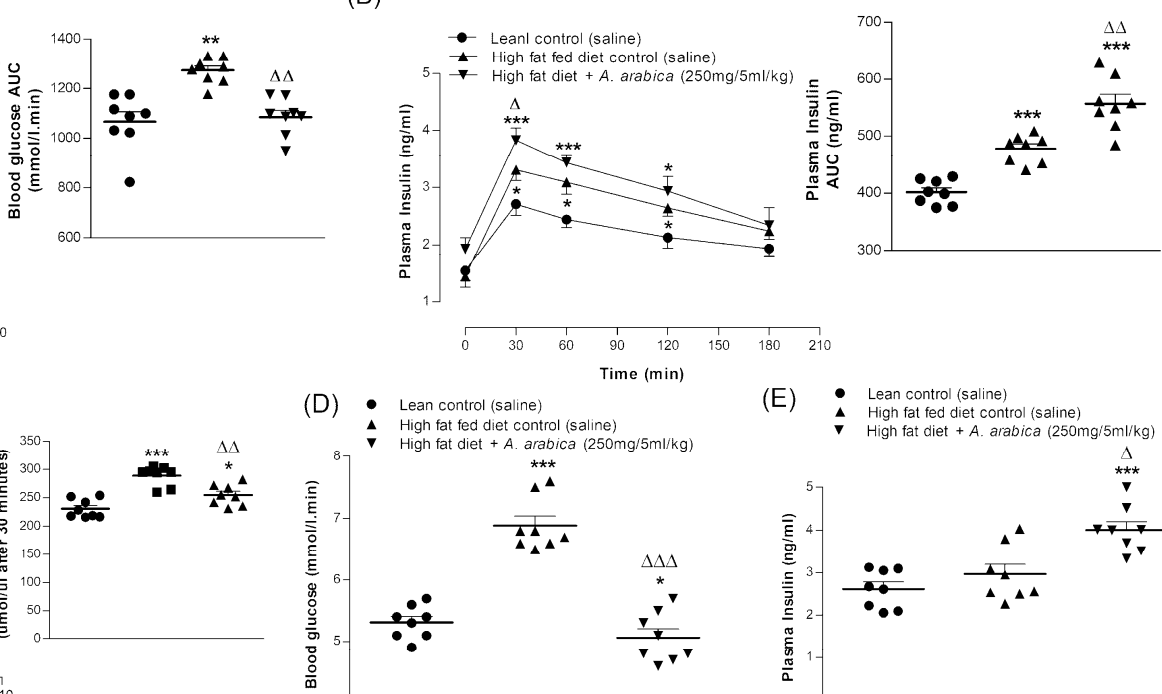

(D) Lean control (saline)

High fat fed diet control (saline)

Time (min)

(E)

(E) $\quad$ Lean control (saline)
High fat fed diet control (saline)

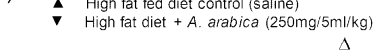

V High fat diet + A. arabica $(250 \mathrm{mg} / 5 \mathrm{ml} / \mathrm{kg})$

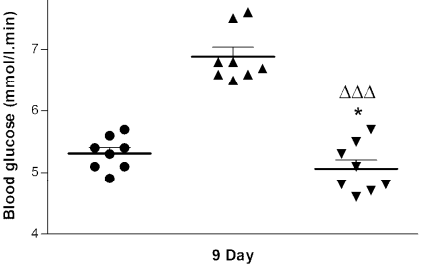

(G)
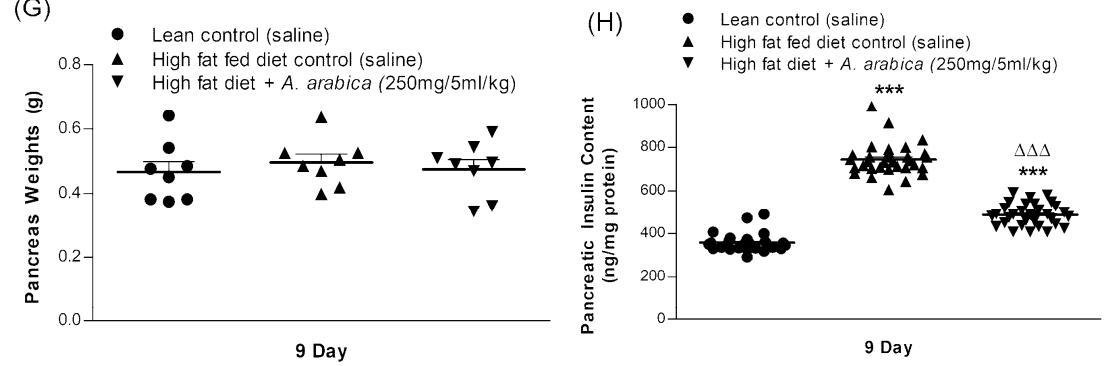

Figure 5. Chronic effects of twice-daily oral administration of hot-water extract of $A$. arabica bark on (A) glucose tolerance, (B) plasma insulin and (C) plasma DPP-IV on Day 6 and (D) blood glucose, (E) plasma insulin, (F) plasma DPP-IV, (G) pancreas weight and (H) pancreatic insulin content on Day 9 in high-fat-fed rats. Parameters were measured after treatment for 6 or 9 days with twice-daily oral administration of hot-water extract of $A$. arabica bark $(250 \mathrm{mg} / 5 \mathrm{~mL} / \mathrm{kg}$ body weight). Values are the mean \pm SEM with $n=8$ ( 32 per group for pancreatic insulin content). ${ }^{*} p<0.05,{ }^{* *} p<0.01$ and ${ }^{* * *} p<0.001$ compared to lean control. ${ }^{\Delta} p<0.05,{ }^{\Delta \Delta} p<0.01$ and ${ }^{\Delta \Delta \Delta} p<0.001$ compared to high-fat-fed control at corresponding time points.

2.12. Effects of Twice-Daily Oral Administration of Hot-Water Extract of A. arabica Bark on Glucose Tolerance in High-Fat-Fed Rats

After 6 days of treatment with A. arabica extract $(250 \mathrm{mg} / 5 \mathrm{~mL} / \mathrm{kg} ; \mathrm{b} . \mathrm{w}$.$) , oral glucose$ tolerance was significantly ( $p<0.05-0.01$ ) improved from $30 \mathrm{~min}$ onward (Figure 5A). The effect was also associated with an increase in plasma insulin after $30 \mathrm{~min}(p<0.05$; Figure 5B). AUC analysis showed a $16 \%$ reduction in blood glucose $(p<0.01$; Figure $5 \mathrm{~A})$ and a $15 \%$ increase in insulin responses $(p<0.01$; Figure $5 \mathrm{~B})$ compared to the high-fat-fed control rats. The extract also inhibited plasma DPP-IV from 60 min onwards (Figure 5C). AUC data showed a $11 \%$ decrease $(p<0.01)$ in enzyme activity compared to high-fat-fed control rats (Figure 5C).

\subsection{Effects of Twice-Daily Oral Administration of Hot-Water Extract of A. arabica Bark on Pancreatic Insulin Content in High-Fat-Fed Rats}

No significant changes were observed in the pancreas weight of treated or untreated high-fat-fed compared with lean control rats (Figure 5G). Pancreatic insulin content in highfat-fed rats was increased by $54 \%(p<0.001)$ (Figure $5 \mathrm{H})$. A. arabica decreased pancreatic insulin compared to high-fat-fed controls $(p<0.001)$, but it was still increased by $35 \%$ $(p<0.001)$ compared to lean rats (Figure $5 \mathrm{H})$. 
2.14. Effects of Twice-Daily Oral Administration of Hot-Water Extract of A. arabica Bark on Islet Morphology in High-Fat-Fed Rats

Representative images of islets of normal, high-fat-fed control and treated high-fat-fed rats are shown in Figure $6 \mathrm{~A}-\mathrm{C})$. High-fat feeding did not change the number of islets per $\mathrm{mm}^{2}$ in the pancreas (Figure $6 \mathrm{~J}$ ), but a significant increase in islet area was observed compared to the normal rats $(p<0.001$; Figure $6 \mathrm{D})$. High-fat-fed rats also exhibited a significant $(p<0.001)$ increase in alpha-cell and beta-cell areas (Figure $6 \mathrm{E}, \mathrm{F})$. Treatment with A. arabica extract significantly reduced overall islet area and beta-cell area $(p<0.05$; Figure 6D,F). As shown in Figure 6G, high-fat-fed rats possessed a greater number of largeand medium-sized islets cells compared to normal control rats. High-fat-fed groups had a higher percentage of $\beta$ cells and a lower proportion of $\alpha$ cells compared with normal rats $(p<0.05-0.01$; Figure 6H,I).

(A)

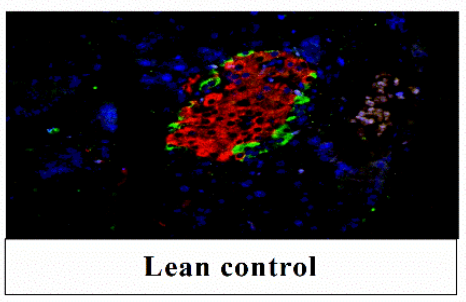

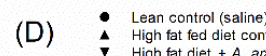
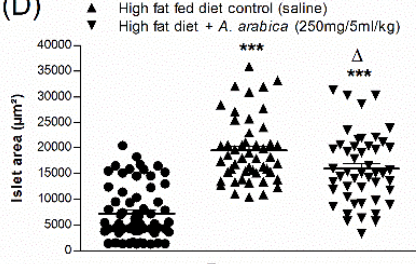

(B)

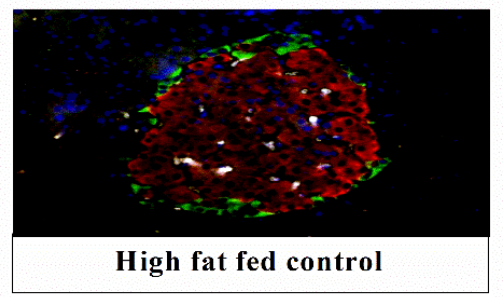

(E)

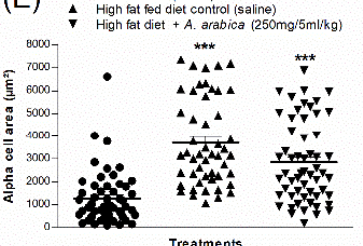

(C)

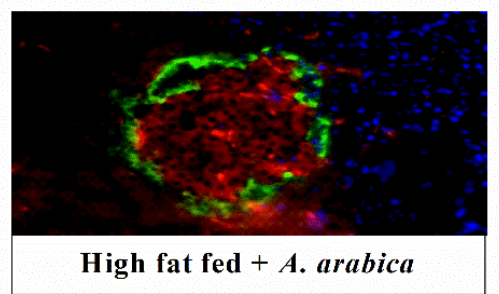

(F)

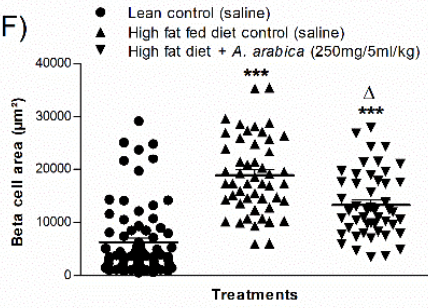

(G)

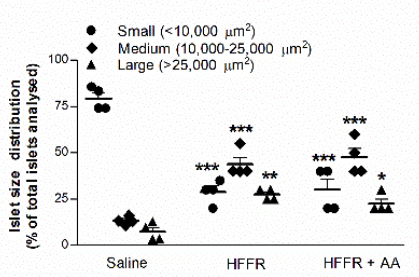

(

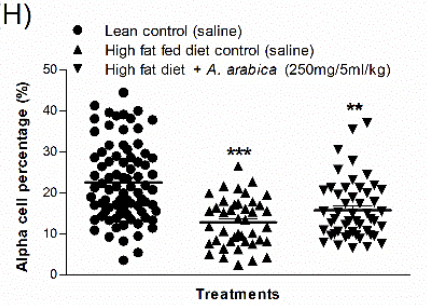

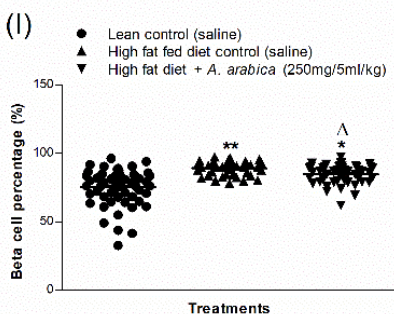

( $)$

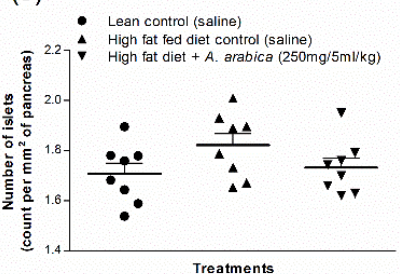

Figure 6. Effects of 9-day twice-daily oral administration of hot-water extract of A. arabica bark on islet morphology in high-fat-fed rats. Representative images of (A) lean control, (B) high-fat-fed control and (C) high-fat-fed plus hot-water extract of A. arabica $(250 \mathrm{mg} / 5 \mathrm{~mL} / \mathrm{kg})$ in rats showing insulin in red, glucagon in green and DAPI in blue, (D) islet area, (E) alpha-cell area, (F) beta-cell area, (G) islet size distribution, $(\mathbf{H})$ alpha-cell percentage, (I) beta-cell percentage and (J) number of islets (per $\mathrm{mm}^{2}$ ), respectively. Values are the mean $\pm \mathrm{SEM}$ for $n=8\left(\sim 50\right.$ islets per group). ${ }^{*} p<0.05,{ }^{* *} p<0.01$ and ${ }^{* * *} p<0.001$ compared to lean control. ${ }^{\Delta} p<0.05$ compared to high fat fed alone (control).

\subsection{Acute Effects of Peak Samples of A. arabica Bark on Insulin Release from BRIN-BD11 Cells}

The five major and clearly defined peak fractions of $A$. arabica bark extract from RPHPLC (Figure 7A) were assayed for insulin-secretory activity using BRIN-BD11 cells as described above. As shown in Figure 7B, all five peak fractions (P-1, P-2, P-3, P-4 and $\mathrm{P}-5)$ significantly stimulated insulin release $(p<0.001)$, as did the $10 \mathrm{mM}$ alanine-positive control. Only P-3 was associated with cytotoxicity, as evidenced by the 2.1-fold increase in cellular LDH release (Figure S1C). 
(A)

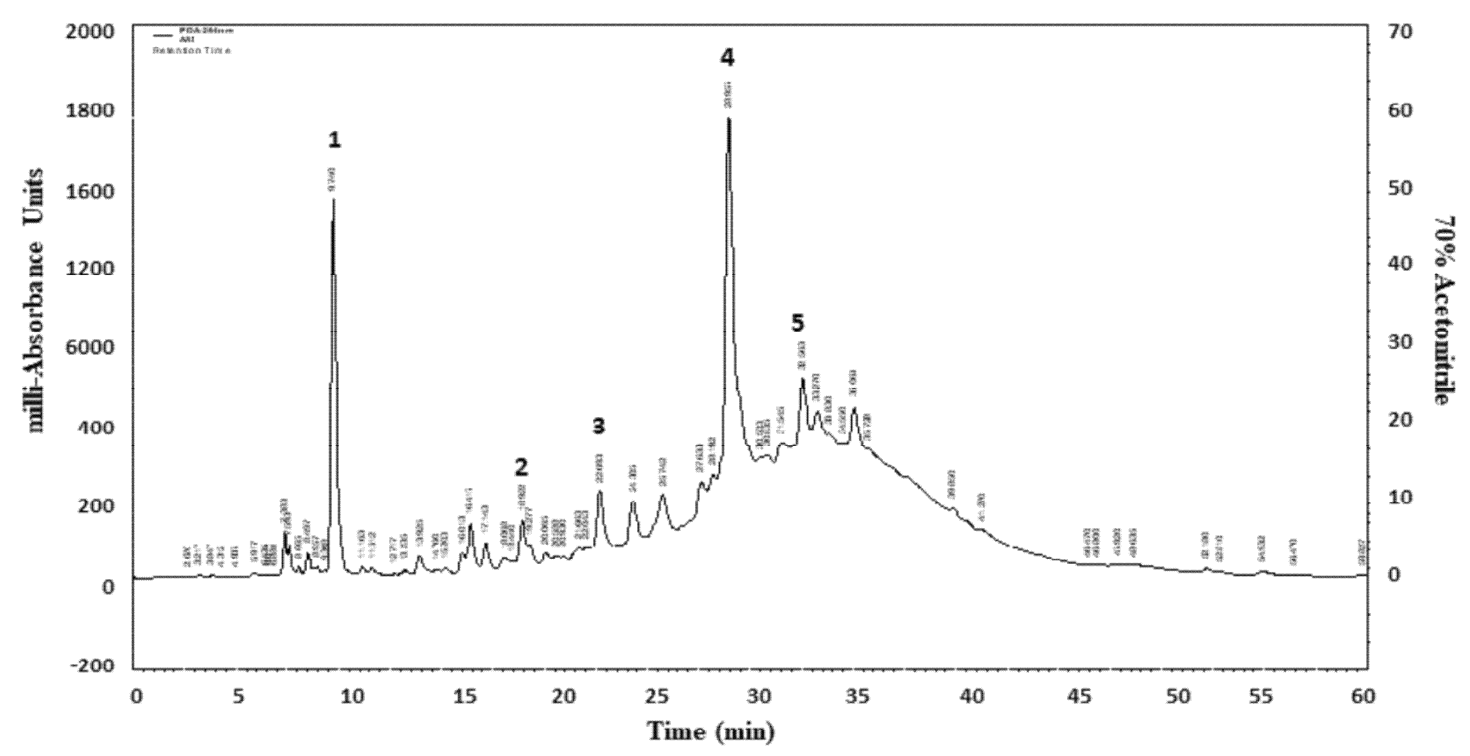

(B)

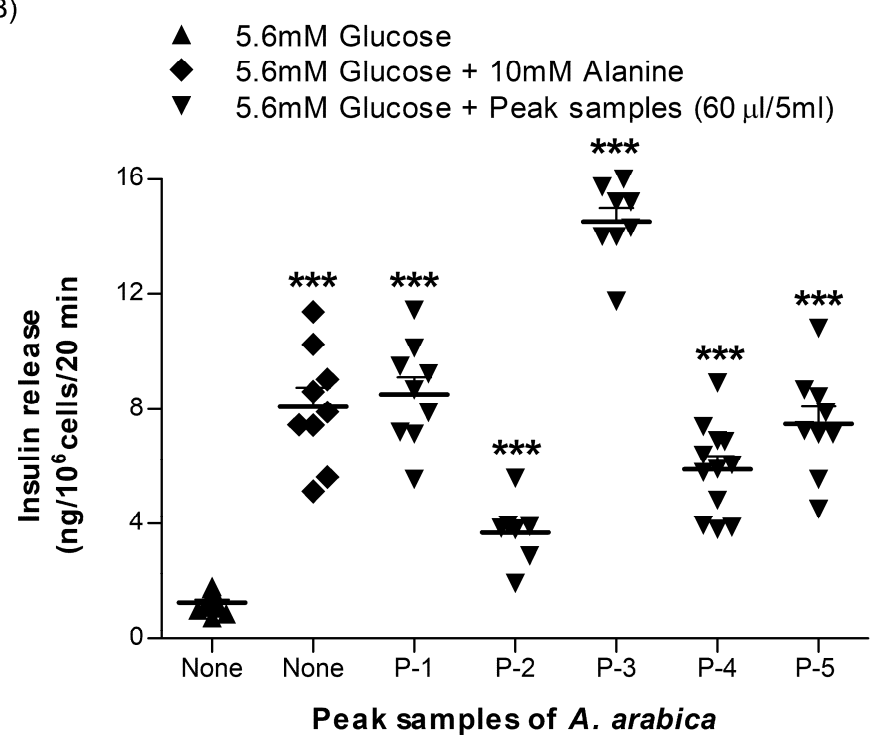

Figure 7. Representative (A) HPLC profile and (B) insulin-releasing effects in BRIN BD11 cells of peak samples (1-5) of hot-water extract of $A$. arabica bark. The crude extract was chromatographed at a flow rate of $1.0 \mathrm{~mL} / \mathrm{min}$ on a $(10 \times 250 \mathrm{~mm})$ semipreparative $5 \mu \mathrm{m} \mathrm{C-18} \mathrm{column} \mathrm{(Phenomenex,} \mathrm{UK).} \mathrm{The} \mathrm{concentration} \mathrm{of} \mathrm{the} \mathrm{eluting} \mathrm{solvent} \mathrm{was} \mathrm{raised} \mathrm{using} \mathrm{linear}$ gradients of acetonitrile (0-20\% from 0 to $10 \mathrm{~min}, 20-70 \%$ from 10 to $40 \mathrm{~min}$ and $70-20 \%$ from 40 to $60 \mathrm{~min}$ ). Compounds were detected by measurement of absorbance at $254 \mathrm{~nm}$, and major peaks labelled P1-P5 were assessed for insulin-releasing activity. Values are the mean $\pm \operatorname{SEM}$ for $n=8 .{ }^{* * *} p<0.001$ compared to control.

\subsection{Purification and Structural Characterisation of Purified Extract of A. arabica Bark}

Compounds were isolated using RP-HPLC and partially characterised by LC-MS (Figure 7A and Table 1). The RP-HPLC and LC-MS analyses predicted that Peaks 1, 2 and 3 were quercetin, catechin and kaempferol, respectively. In the case of quercetin, compound identity was further probed by NMR. Isolated compound quercetin was analysed through ${ }^{1} \mathrm{H}$ and ${ }^{13} \mathrm{C}$ NMR for characterisation: $\mathrm{C}_{15} \mathrm{H}_{10} \mathrm{O}_{7}$ was obtained as a yellow powder, $\lambda$ max $=360,256 \mathrm{~nm}$; EI-MS m/z 301.2 Da [M]; $600 \mathrm{MHz}, \mathrm{CD} 3 \mathrm{OD},{ }^{1} \mathrm{H}-\mathrm{NMR}(\delta$ in ppm); 6.19 (d, $\left.{ }^{1} \mathrm{H}, J=2 \mathrm{~Hz}, \mathrm{H}-6\right), 6.40\left(\mathrm{~d},{ }^{1} \mathrm{H}, J=2 \mathrm{~Hz}, \mathrm{H}-8\right), 6.88\left(\mathrm{~d},{ }^{1} \mathrm{H}, J=8.4 \mathrm{~Hz}, \mathrm{H}-5^{\prime}\right), 7.64\left(\mathrm{~d},{ }^{1} \mathrm{H}, J\right.$ $\left.=7.4 \mathrm{~Hz}, \mathrm{H}-6^{\prime}\right)$ and $7.80\left(\mathrm{~d},{ }^{1} \mathrm{H}, J=2 \mathrm{H}, \mathrm{H}-2^{\prime}\right) .{ }^{13} \mathrm{C}$ NMR $\left(600 \mathrm{MHz}, \mathrm{CD}_{3} \mathrm{OD}, \delta\right.$ in ppm); 
147.4 (C-2), 135.8 (C-3), 175.9 (C-4), 161.1 (C-5), 97.8 (C-6), 164.1 (C-7), 93.0 (C-8), 156.8 (C-9), $103.1(\mathrm{C}-10), 122.3\left(\mathrm{C}-1^{\prime}\right), 115.6\left(\mathrm{C}-2^{\prime}\right), 145.6\left(\mathrm{C}-3^{\prime}\right), 147.7\left(\mathrm{C}-4^{\prime}\right), 116.1\left(\mathrm{C}-5^{\prime}\right)$ and $119.2\left(\mathrm{C}-6^{\prime}\right)$.

Table 1. Molecular mass and predicted identity of peak samples of A. arabica bark obtained from the preparative RP-HPLC via LC-MS analysis.

\begin{tabular}{ccccc}
\hline Peak Samples & $\begin{array}{c}\text { Retention Time } \\
(\mathbf{m i n})\end{array}$ & $\begin{array}{c}\text { Theoretical } \\
\text { Molecular } \\
\text { Wt. (Da) }\end{array}$ & $\begin{array}{c}\text { Found } \\
\text { Molecular } \\
\text { Weight (Da) }\end{array}$ & $\begin{array}{c}\text { Predicted } \\
\text { Compounds }\end{array}$ \\
\hline$P_{1}$ & 9.7 & 302.2 & 301.2 & Quercetin \\
\hline$P_{2}$ & 19 & 290.3 & 289.0 & Catechin \\
\hline$P_{3}$ & 23 & 286.2 & 285.2 & Kaempferol \\
\hline$P_{4}$ & 29 & - & 677.2 & Unknown \\
\hline$P_{5}$ & 32.5 & - & 496.9 & Unknown \\
\hline
\end{tabular}

Peaks were separated on a Spectra System LC using a Kinetex $5 \mu \mathrm{m}$ F5 LC column $\left(150 \times 4.6 \mathrm{~mm}^{2}\right)$ (Phenomenex). The mass-to-charge ratio $(\mathrm{m} / \mathrm{z})$ versus peak intensity was determined.

The ${ }^{1} \mathrm{H}-\mathrm{NMR}$ spectrum of the isolated compound showed aromatic hydrogen groups from 6.19 to $7.80 \mathrm{ppm}$. The ${ }^{13} \mathrm{C}-\mathrm{NMR}$ spectrum showed a carbonyl group at $175.9 \mathrm{ppm}$ and an aromatic carbon group from 93.0 to $164.1 \mathrm{ppm}$. The structure was verified via comparison with evidence from the literature [20,21]. Molecular structures of tentatively identified compounds are outlined in Figure 8A-C.

(A)<smiles>O=c1c(O)c(-c2ccc(O)c(O)c2)oc2cc(O)cc(O)c12</smiles>

Quercetin
(B)<smiles>Oc1cc(O)c2c(c1)OC(O)C(c1ccc(O)c(O)c1)C2</smiles>

Catechin
(C)<smiles>O=c1c(O)c(-c2ccc(O)cc2)oc2cc(O)cc(O)c12</smiles>

Kaempferol

Figure 8. Isolated compounds (A) quercetin, (B) catechin and (C) kaempferol of Peak-1, -2 and -3 samples obtained from RP-HPLC of hot-water extract of $A$. arabica bark via LC-MS analysis. Proton-decoupled natural abundance ${ }^{1} \mathrm{H}-\mathrm{NMR}$ and $\mathrm{C}^{13}$-NMR of the Peak-1 sample of $A$. arabica bark (obtained from a chromatograph over the period of $70 \%$ acetonitrile from 10 to $40 \mathrm{~min}$ with a retention time of $9.7 \mathrm{~min}$ ) at $40{ }^{\circ} \mathrm{C}$. The spectrum values were obtained at $600 \mathrm{MHz}$ after 119,044 transients $(14 \mathrm{~h})$ by the pulsed Fourier-transform method on a Varian XL-100 A spectrometer. The representative structures of flavonoids, corresponding to the molecular formula of quercetin, catechin and kaempferol, are $\mathrm{C}_{15} \mathrm{H}_{10} \mathrm{O}_{7}, \mathrm{C}_{15} \mathrm{H}_{14} \mathrm{O}_{6}$ and $\mathrm{C}_{15} \mathrm{H}_{10} \mathrm{O}_{6}$.

\subsection{Acute Effects of Isolated Compounds Quercetin and Kaempferol on Insulin Release from BRIN-BD11 Cells}

Quercetin and kaempferol isolated from A. arabica bark were tested to confirm insulinsecretory activity using BRIN-BD11 cells (Figure $9 A, B)$. Alanine $(10 \mathrm{mM})$ was again used as positive control. Quercetin stimulated insulin secretion at 1.56-50 $\mu \mathrm{M}(p<0.05-0.001$, Figure 9A), but at $50 \mu \mathrm{M}$ increased LDH release by 2.1-fold (Figure S1D). Kaempferol also increased insulin release in a dose-dependent manner $(6.25-100 \mu \mathrm{M} ; p<0.01-0.001$, Figure 9B) from BRIN-BD11 cells. At concentrations $\geq 100 \mu \mathrm{M}$, this was associated with cytotoxicity and increased LDH release by 1.25 -fold (Figure S1E). 


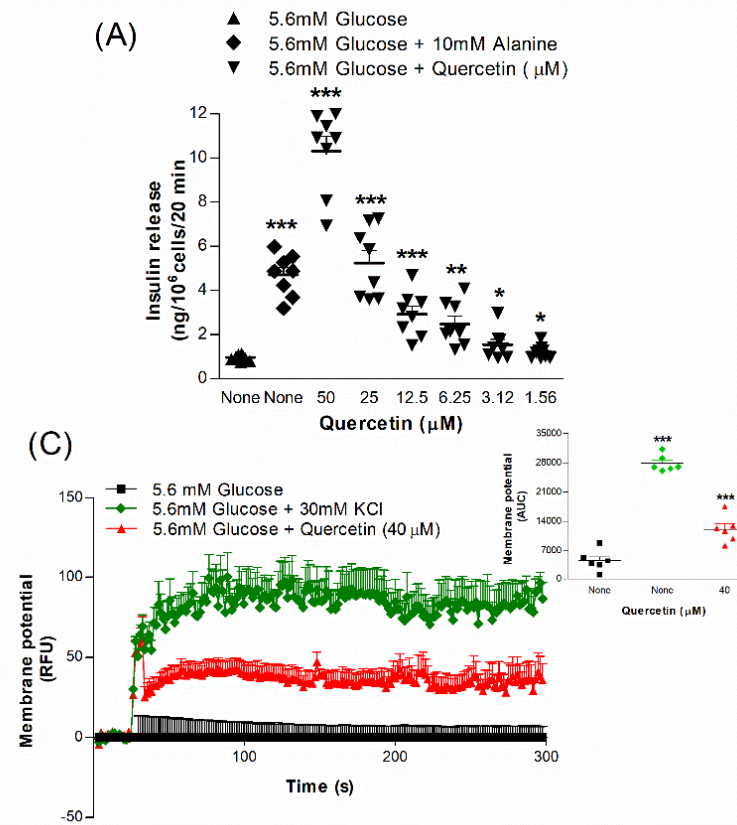

(B)
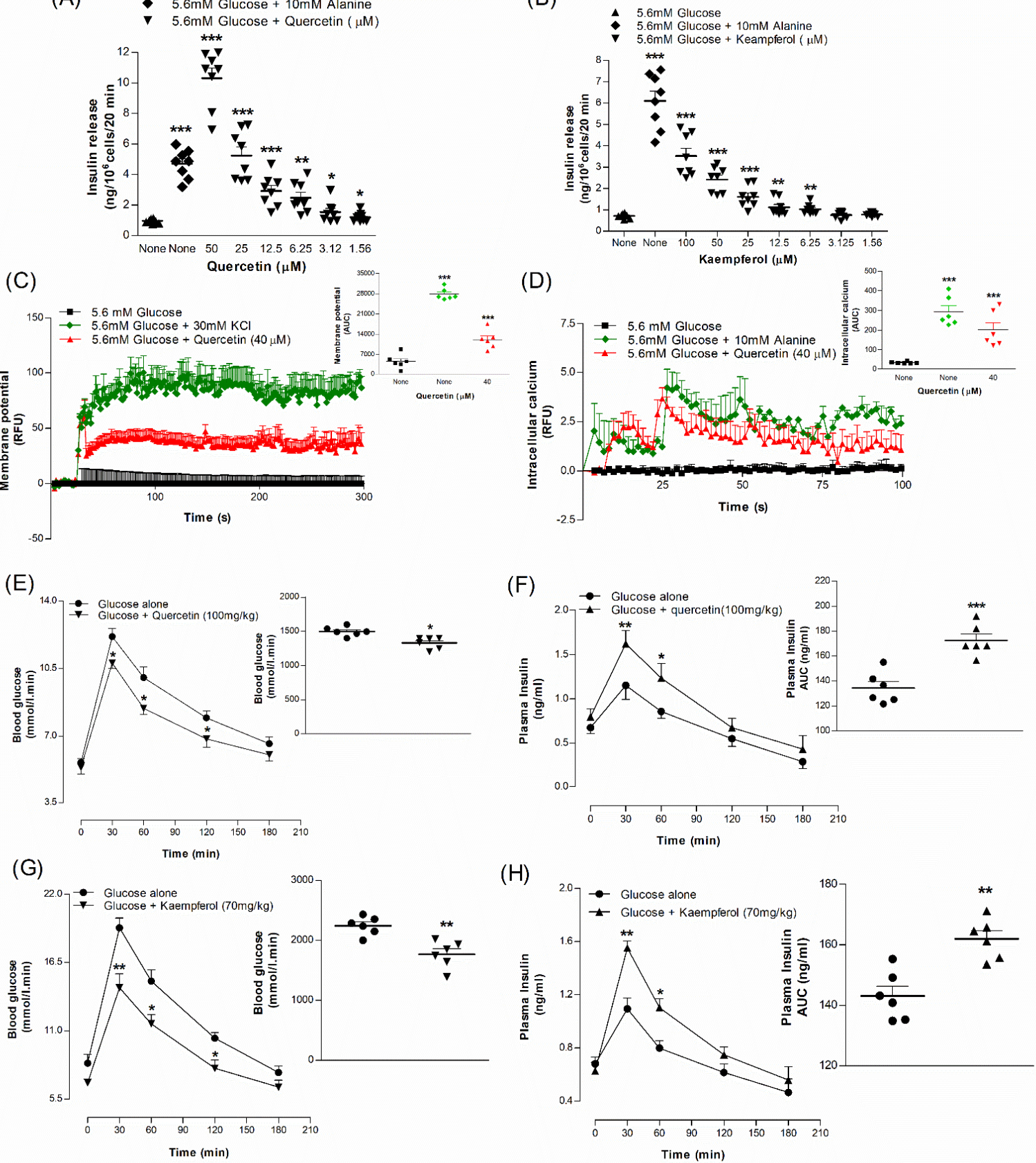

Figure 9. Insulin-releasing effects of (A) Quercetin and (B) Kaempferol, (C) membrane potential and (D) intracellular calcium from BRIN-BD11 cells, $(\mathbf{E}, \mathbf{G})$ glucose tolerance and $(\mathbf{F}, \mathbf{H})$ plasma insulin. Mice were fasted for $12 \mathrm{~h}$ and administered glucose $(18 \mathrm{mmol} / \mathrm{kg}$ body weight) by oral gavage with or without (E,F) simultaneous quercetin $(100 \mathrm{mg} / \mathrm{kg} \mathrm{b.w.)} \mathrm{and}$ $(\mathbf{G}, \mathbf{H})$ kaempferol (70 mg $/ \mathrm{kg}$ b.w.). Values are the mean \pm SEM for $n=8$ for insulin release, $n=6$ for membrane potential, intracellular calcium, glucose tolerance and plasma insulin. ${ }^{*} p<0.05,{ }^{* *} p<0.01$ and ${ }^{* * *} p<0.001$ compared to control.

\subsection{Effects of Isolated Compound Quercetin on Membrane Depolarisation and $\left(\left[\mathrm{Ca}^{2+}\right]_{i}\right.$ in} BRIN-BD11 Cells

Quercetin $(40 \mu \mathrm{M})$ depolarised BRIN-BD11 cells in the presence of $5.6 \mathrm{mM}$ glucose (Figure 9 C). Similarly, quercetin at $40 \mu \mathrm{M}$ substantially $(p<0.001)$ increased $\left[\mathrm{Ca}^{2+}\right]_{\mathrm{i}}$ compared to control (Figure $9 \mathrm{D}) . \mathrm{KCl}(30 \mathrm{mM})$ and alanine $(10 \mathrm{mM})$ were used as positive controls. 


\subsection{Acute Effects of Synthetic Compound Quercetin and Kaempferol on Oral Glucose Tolerance in Mice}

Oral glucose tolerance was significantly improved $(p<0.05-0.01)$ at 30, 60 and $120 \mathrm{~min}$ when quercetin $(100 \mathrm{mg} / \mathrm{kg})$ or kaempferol $(70 \mathrm{mg} / \mathrm{kg})$ were co-administered with glucose (18 mmol/kg body weight) to mice (Figure 9E,G). Plasma insulin concentrations were also increased at 30 and $60 \mathrm{~min}(p<0.05-0.01$; Figure 9F,H). AUC analysis showed an 11-22\% $(p<0.01)$ decrease in blood glucose and a $22-24 \%(p<0.01)$ increase in plasma insulin responses, respectively (Figure 9E-H).

\section{Discussion}

A. arabica, commonly known as babul, has been reported to possess antidiabetic properties by traditional healers and recent scientific reports [22]. However, the validity of these claims and the molecular mechanisms underpinning its antidiabetic activity have not been elucidated $[23,24]$. To address this, we utilised a platform of in vitro tests and high-fat-fed rats to test potential antihyperglycaemic actions of hot-water extract of $A$. arabica bark.

We first evaluated the insulinotropic activity of $A$. arabica using clonal rat BRIN-BD11 cells and isolated mouse islets. This revealed stimulatory concentration-dependent insulinsecretory effects at nontoxic concentrations. Further assessment was made using fluorescent indicator dyes and known modulators of $\beta$-cell function, including diazoxide, verapamil, $\mathrm{Ca}^{2+}$ depletion, tolbutamide, $\mathrm{KCl}$ and IBMX. These studies revealed that the action of $A$. arabica involved the closure of K-ATP channels, membrane depolarisation, the opening of voltage-dependent calcium channels, the influx of $\mathrm{Ca}^{2+}$ and the elevation of intracellular $\mathrm{Ca}^{2+}$. Stimulatory effects nevertheless persisted in $\beta$ cells depolarised by tolbutamide or $30 \mathrm{mM} \mathrm{KCl}$, suggesting additional actions such as the activation of adenylate cyclase, which is supported by positive potentiation by the phosphodiesterase inhibitor, IBMX [25].

Insulin works primarily on skeletal muscle and adipose tissue for postprandial glucose regulation [26]. GLUT4 translocation is reduced, and an inadequate or defective signal leads to the development of insulin resistance [27]. Agents that can resolve insulin resistance are therefore of great utility for the treatment of T2DM [28]. In this study, A. arabica increased the glucose uptake by 3T3L1 adipocytes. The mechanisms responsible for such action need further clarification but might involve the activation of Akt and p70 kinase, as this has been shown to increase glycogen, lipid, and protein synthesis and in turn promote glucose uptake [29].

Several factors are involved in the pathophysiology of diabetes and its complications, such as the hyperglycaemic-induced glycation of structural and functional proteins [30]. Previous in vivo studies have reported that insulin can be glycated and reduces its biological activity by approximately $10 \%$, thereby contributing to insulin resistance [31,32]. Inhibition of the glycation of insulin and other proteins is therefore a desirable feature of any antidiabetic remedy. In this study, A. arabica decreased insulin glycation in vitro in a concentration-dependent manner. This might reflect the antioxidant properties and phytoconstituents of the plant such as vitamin C, flavonoids, glycosides, quercetin and gallic acids [33,34].

A. arabica was tested for its effects on the in vitro enzymatic digestion of starch by $\alpha$ amylase and $\alpha$-glucosidase, leading to the liberation of glucose. Acarbose, an established $\alpha$ glucosidase inhibitor used as a reference standard, inhibited glucose liberation significantly in a concentration-dependent manner. A. arabica also caused significant concentrationdependent inhibition of glucose liberation from starch. Previous studies have reported that flavonoids are very effective in reducing the $\alpha$-amylase activity and slowing down starch digestion [35]. It has also been reported that A. arabica contains a high fibre content [36], which may slow gastric emptying.

A decrease in the absorption and diffusion of glucose from the gastrointestinal tract is one of the many reasons for plants to exhibit antihyperglycaemic activity [37]. We used a dialysis-based method to study the effects of plant extract on the diffusion of glucose 
through an artificial barrier. Although this method has certain limitations, such as being unphysiological and needing lengthy dialysis time (22-24 h), this technique is a simple and effective means to study the effects of viscosity on glucose diffusion. The glucose absorption blocker, guar gum, was used as positive control. In this system, A. arabica extract elicited significant concentration-dependent inhibition of glucose movement through the dialysis membrane.

High-fat diet-induced obese diabetic rodents are frequently used as models for investigating both the acute and chronic effects of plant extract and pharmaceutical products [38]. Oral administration of $A$. arabica, together with glucose to high-fat-fed rats, improved glucose tolerance, decreased circulating DPP-IV and augmented the accompanying plasma insulin response. In the follow-up chronic 9-day study, A. arabica elicited significant improvements in food intake, body weight, non-fasting glucose, glucose tolerance, plasma insulin and circulating DPP-IV. These observations support earlier studies showing that $A$. arabica decreased hyperglycaemia, TC, TG, LDL-C and MDA and increased HDL-C and Co-Q10 in STZ-induced diabetic rats [19].

The observation that benefits of $A$. arabica may extend to STZ rats typified by beta-cell destruction suggests a possible positive effect on islet morphology and beta-cell mass. Because we showed that the plant inhibits DPP-IV both in vitro and in vivo, the incretin hormones GLP-1 and GIP may play a role in mediating such effects, as both peptides are known to exert positive effects on $\beta$-cell proliferation, apoptosis, and islet cell transdifferentiation [39-41]. Thus, by inhibiting DPP-IV, A. arabica will block the degradation of GIP and GLP-1 to their inactive metabolites GLP-1 (9-36) and GIP (3-42) [42,43], thereby promoting concentrations of their active forms. Several studies claim that phytochemicals in many plant species have the potential to inhibit DPP-IV by directly blocking the DPP-IV enzyme ligand-binding site $[44,45]$. Based on our phytochemical analysis of A. arabica extract, it seems likely that flavonoids are the active compounds responsible for DPP-IV enzyme inhibitory action. However, further studies are clearly needed to confirm this hypothesis.

Interestingly, histological analysis of the pancreas of high-fat-fed rats in the present study revealed that $A$. arabica countered the diet-induced increases in islet, beta-cell and alpha-cell areas associated with insulin resistance. The pancreatic insulin content was also increased in the high-fat-fed group, being associated with a greater number of large- and medium-sized islets with no overall change in the total number of islets per $\mathrm{mm}^{2}$. It seems likely that these effects of $A$. arabica are not directly mediated by plant phytochemicals but are a consequence of the amelioration of hyperglycaemia and improvement of insulin resistance. However, further studies would be useful to confirm this.

Due to increasing interest in the availability of biologically or pharmacologically active compounds, the search for phytochemicals responsible for the bioactivity of crude plant extract has gained significant prominence. In this study, A. arabica crude extract was further analysed to isolate, identify, and characterise molecular compounds with insulinotropic and antidiabetic activity. Five major peaks (P-1 to P-5) were isolated by RP-HPLC and shown to stimulate insulin release from clonal $\beta$ cells. Further analysis showed identity similar to the known phytochemicals quercetin (P-1), catechin (P-2) and kaempferol (P3) [46]. The isolated fraction P-1 (quercetin) was a yellow amorphous powder that was further characterised by NMR. This revealed that the ${ }^{1} \mathrm{H}-\mathrm{NMR}$ spectrum of the isolated compound had aromatic hydrogen groups from 6.19-7.80 ppm. The ${ }^{1} \mathrm{H}-\mathrm{NMR}$ spectrum showed two peaks at $6.19\left(\mathrm{~d},{ }^{1} \mathrm{H}, J=2 \mathrm{~Hz}\right)$ and $6.40 \mathrm{ppm}\left(\mathrm{d},{ }^{1} \mathrm{H}, J=2 \mathrm{~Hz}\right)$, consistent with the meta protons on the A ring and at $6.88\left(\mathrm{~d},{ }^{1} \mathrm{H}, J=8.4 \mathrm{~Hz}\right), 7.64\left(\mathrm{~d},{ }^{1} \mathrm{H}, J=7.4 \mathrm{~Hz}\right)$ and $7.80\left(\mathrm{~d},{ }^{1} \mathrm{H}, J=2 \mathrm{~Hz}\right)$ corresponding to the catechol protons on the $\mathrm{B}$ ring. The ${ }^{13} \mathrm{C}-\mathrm{NMR}$ spectrum showed a carbonyl group at $175.9 \mathrm{ppm}$ and an aromatic carbon group from 93.0 to $164.1 \mathrm{ppm}$. These data are consistent with those reported in the literature for the compound quercetin [20,21]. Quercetin and kaempferol significantly increased insulin release in a concentration-dependent manner and improved both glucose tolerance and plasma insulin responses in mice. Quercetin (P-1), catechin (P-2) and kaempferol (P-3) have been suggested to have significant antidiabetic potential [47], and the presence of 
these phytochemicals might be responsible for the substantial antidiabetic activity of $A$. arabica bark.

\section{Materials and Methods}

\subsection{Collection and Preparation of Plant Extracts}

The bark of $A$. arabica was collected from Jahangirnagar University, Dhaka, Bangladesh, and Botanical Accession Number 43,756 was assigned by the National Herbarium. Barks were processed for hot-water extraction, as described previously [48]. The final extracted semisolid, sticky residue of $A$. arabica bark was freeze-dried using a freeze dryer (Varian 801 LY-3-TT, Varian, Lexington, MA, USA) and stored at $4{ }^{\circ} \mathrm{C}$ until use. Flavonoids, including quercetin, catechin and kaempferol, were obtained from Sigma-Aldrich (Poole, UK).

\subsection{In Vitro Insulin-Releasing Studies}

Insulin-releasing BRIN BD11 cells were generated by the electrofusion of New England Deaconess Hospital rat pancreatic beta cells with immortal clonal RINm5F islet cells [49]. The insulin secretion from clonal BRIN-BD11 cells and mouse islets was observed as per a previous description [50]. Plant extract was incubated with or without known modulators of insulin secretion at 1.1, 5.6 or $16.7 \mathrm{mM}$ glucose, respectively. Dextran-coated charcoal radioimmunoassay was used to measure insulin in the aliquoted supernatant samples, which were stored at $-20{ }^{\circ} \mathrm{C}$ [48]. For the analysis of insulin content, islets were extracted at $4{ }^{\circ} \mathrm{C}$ for $24 \mathrm{~h}$, and supernatant samples collected after centrifugation for $2 \mathrm{~min}$ at $1200 \mathrm{rpm}$ were stored at $-20^{\circ} \mathrm{C}$ prior to radioimmunoassay [49].

\subsection{Membrane Potential and Intracellular Calcium ([Ca $\left.{ }^{2+}\right]$ i)}

To measure the intensity of membrane depolarisation and $\left[\mathrm{Ca}^{2+}\right] \mathrm{i}$ of BRIN-BD11 cells with $A$. arabica extract, we used the FLIPR Membrane Potential and $\left[\mathrm{Ca}^{2+}\right] \mathrm{i}$ Assay Kit (Molecular Devices, Sunnyvale, CA, USA) [49]. In brief, clonal pancreatic beta cells were seeded on 96-well plates for $18 \mathrm{~h}$ at $37^{\circ} \mathrm{C}$ to allow attachment. The medium was then removed, and $100 \mu \mathrm{L} \mathrm{KRBB}$ of $5.6 \mathrm{mM}$ glucose at $37^{\circ} \mathrm{C}$ was added. After $10 \mathrm{~min}, 100 \mu \mathrm{L}$ of FLIPR membrane potential or calcium dye was added, and the cells were incubated for $60 \mathrm{~min}$ at $37^{\circ} \mathrm{C}$. Signal intensity changes were measured using FlexStation 3 (Molecular Devices, Sunnyvale, CA, USA).

\subsection{Cellular Glucose Uptake}

The 3T3 L1 differentiated adipose cells were used to estimate the glucose uptake [51]. The cells were seeded in 24 -well plates and kept in an incubator at $37^{\circ} \mathrm{C}$ for 30 min with $A$. arabica in the presence or absence of $100 \mathrm{nM}$ insulin before incubation with 2-NBDG (50 $\mathrm{nM})$ for 5 min. Every single well was washed twice with ice-cold PBS, and slides were covered with three to four coverslips. By using a microscope with $10 \times$ magnification, four images of the coverslips were taken in order to measure glucose uptake with fluorescence intensity.

\subsection{Insulin Glycation}

Insulin glycation in the presence of $A$. arabica was assessed following a previous description [52]. During the experiment, incubation of D-glucose (246.5 mM) with human insulin $(1 \mathrm{mg} / \mathrm{mL})$ and $\mathrm{NaBH} 3 \mathrm{CN}(0.0853 \mathrm{gm} / \mathrm{mL})$ with or without HWAA $(8,40$, $200 \mu \mathrm{g} / \mathrm{mL}$ ) was performed. A day later, $0.5 \mathrm{M}$ acetic acid was added to stop the reaction. RP-HPLC was used to measure glycated and nonglycated insulin [31].

\subsection{DPP-IV Enzyme Activity In Vitro}

The DPP-IV enzyme inhibitory actions of $A$. arabica were estimated following an earlier report [43]. The chemical reagents, including $8 \mathrm{mU} / \mathrm{mL}$ of DPP-IV enzyme and $200 \mu \mathrm{M}$ of substrate (Gly-Pro-AMC), were incubated with treatment groups in 96-well plates and processed as per a previous description [41]. Visual changes in the fluorescence 
were analysed by excitation at $370 \mathrm{~nm}$ and emission at $440 \mathrm{~nm}$ with a $2.5 \mathrm{~nm}$ slit width by FlexStation 3 (Molecular Devices, Sunnyvale, CA, USA).

\subsection{Starch Digestion}

Extract effects on starch digestion [53] were measured by incubating A. arabica or acarbose in starch solution (100 mg) (Sigma-Aldrich, St. Louis, MO, USA). Heat-stable $\alpha$-amylase $(0.01 \%)$ from Bacillus leicheniformis and amyloglucosidase $(0.1 \%)$ from Rhizopus mould (Sigma-Aldrich, St. Louis, USA) were added to the mixture after dilution. Final samples were stored for further analysis of glucose release by utilising the GOD/PAP method (Randox GL 2623).

\subsection{Glucose Diffusion}

Cellulose ester (CE) dialysis tubes $(20 \mathrm{~cm} \times 7.5 \mathrm{~mm}$, MWCO: 2000, Spectrum, The Netherland) were employed to estimate glucose diffusion in vitro following a recent study [54]. The solution of $220 \mathrm{mM}$ glucose $(2 \mathrm{~mL})$ was loaded into the tubes in the presence or absence of treatments (including A. arabica and guar gum). The tubes with closed ends were placed inside $0.9 \% \mathrm{NaCl}(45 \mathrm{~mL})$ solution with continuous shaking for $24 \mathrm{~h}$ at $37^{\circ} \mathrm{C}$. The amount of glucose that pierced the tube was assessed.

\subsection{Animals}

A high-fat diet ( $20 \%$ protein, $45 \%$ fat and $35 \%$ carbohydrate, $26.15 \mathrm{KJ} / \mathrm{g}$ total energy percentage, Special Diet Service, Essex, UK) was fed to Sprague-Dawley male rats for $150-180$ days prior to the study. A standard diet (10\% fat, 30\% protein and $60 \%$ carbohydrate, $12.99 \mathrm{KJ} / \mathrm{g}$ total energy, Trouw Nutrition, Cheshire, UK) was fed to lean control rats. Additional experiments to test the effects of quercetin and kaempferol were conducted to see the improvement in glucose tolerance in 6-week old normal male Swiss albino mice (Envigo).

\subsection{Ethical Approval}

The Animal Welfare and Ethical Review Board (AWERB) at Ulster University approved the studies, performed based on the UK Animals (Scientific Procedures) Act 1986 and EU Directive 2010/63EU. Precautions were taken to avoid any discomfort with rodents.

\subsection{Oral Glucose Tolerance and Plasma DPP-IV}

Fasted high-fat-fed rats $(12 \mathrm{~h})$ or mice $(6 \mathrm{~h})$ were used to see the impact of HWAA $(250 \mathrm{mg} / 5 \mathrm{~mL} / \mathrm{kg}$ ) and isolated compounds (quercetin and kaempferol) $(100$ and $70 \mathrm{mg} / \mathrm{kg}$ ) on blood glucose control [49]. An oral glucose tolerance test after the administration of glucose with or without simultaneous treatment with A. arabica was performed. Blood collected from tail tips at different time points mentioned in the figures was used for glucose (Figures 3 and 5 for $6 \mathrm{~h}$ and Figure 9 for $12 \mathrm{~h}$ ) and plasma insulin measurement [55]. Enzymatic (DPP-IV) assay in plasma was performed following a previous report [43], as given above.

\subsection{Glucose Homeostasis in Obese Rats}

A. arabica $(250 \mathrm{mg} / 5 \mathrm{~mL} / \mathrm{kg}$ body weight) or $0.9 \%(w / v)$ saline vehicle was administered orally twice a day in high-fat-fed rats for 9 successive days. At a particular time interval, parameters such as blood glucose and plasma insulin were assessed. Following 6 days of treatment, OGTT $(18 \mathrm{mmol} / \mathrm{kg})$ was performed in 12 fasted rats. At the completion of the study, pancreatic tissues were extracted according to a previous report [49].

\subsection{Islet Morphology Studies in Obese Rats}

Pancreatic tissues were sliced into 5 to $8 \mu \mathrm{M}$ sections, fixed, processed, stained and analysed [56]. Sections were incubated with both a primary antibody (mouse anti-insulin (1:500) and guinea pig anti-glucagon (1:400)) and secondary antibody mixture (Alexa Fluor 
594 goat anti-mouse antibody and Alexa Fluor 488 goat anti-guinea pig antibody) at $4{ }^{\circ} \mathrm{C}$ (overnight) and room temperature, respectively. Subsequent to staining the nucleus with $4^{\prime}$,6-diamidino-2-phenylindole (DAPI), the slides were mounted and analysed following a previous description [2].

\subsection{Purification of Crude Extracts}

The filtered extract was injected into a Vydac 218TP1022 (Grace, Deerfield, IL, USA) preparative stainless-steel column $(\mathrm{C}-18,10 \mu \mathrm{m})\left(22 \times 250 \mathrm{~mm}^{2}\right)$ at a $5.0 \mathrm{~mL} / \mathrm{min}$ flow rate with $0.12 \%(v / v)$ TFA/water. Acetonitrile concentration in the eluting solvent was mounted using linear gradients to $20 \%$ for $10 \mathrm{~min}$ and to $70 \%$ over a period of $40 \mathrm{~min}$. Major peaks were tested for insulinotropic activity, as detailed above, and positive fractions were purified again at a flow rate of $1.0 \mathrm{~mL} / \mathrm{min}$ following recent studies [2,57].

\subsection{Determination of Molecular Weight}

LC-MS was implemented to measure the molecular weight of selected peak fractions of A. arabica obtained from RP-HPLC via ESI-MS. A Spectra System LC (Thermo Separation Products) containing a Kinetex $5 \mu \mathrm{m}$ F5 LC column $\left(150 \times 4.6 \mathrm{~mm}^{2}\right)$ was used to identify the identity of the peak fraction as previously reported [58].

\subsection{Confirmation of Purity and Identity}

The tentative identification of compounds using HPLC and LC-MS was further analysed via nuclear magnetic resonance (NMR) [59]. A $600 \mathrm{MHz}$ Bruker AVIII HD spectrometer outfitted with a $5 \mathrm{~mm}$ BBO $\mathrm{H}$ and $\mathrm{F}$ cryogenic test was implemented to record NMR spectra. The ${ }^{1} \mathrm{H}$ NMR and ${ }^{13} \mathrm{C}$ NMR spectra were obtained by implementing standard one-dimensional composite pulse sequencing (zgcppr) and the aid of the use of the reverse gated-decoupling pulse sequence (zgig), respectively, and the parameters were set according to a previous description [59].

\subsection{Statistical Analysis}

For all statistical analysis and interpretation of data, GraphPad Prism 5 was used. Data were analysed using the unpaired Student's $t$-test (nonparametric, with two-tailed $p$-values) and one-way ANOVA with the help of Bonferroni post hoc tests. Values were introduced as the mean $\pm \mathrm{SEM}$, and $p<0.05$ was set as the significant limit.

\section{Conclusions}

In conclusion, the present study provides definitive evidence for the antidiabetic properties of $A$. arabica bark in high-fat-fed (HFF) obese diabetic rats and reveals that this is due to a broad spectrum of pancreatic and extrapancreatic actions. These serve to enhance insulin secretion, promote insulin action and cellular glucose uptake together with retardation of the digestion and absorption of glucose from food. Phytochemicals responsible for $\beta$-cell effects include quercetin, kaempferol and catechin. Such herbal remedies based on A. arabica might provide a validated, accessible, and useful adjunctive diabetic treatment, especially in the areas that do not have easy access to established therapies. However, further studies are warranted to assess the potential use of $A$. arabica and its marker compounds in the prevention and management of type 2 diabetes.

Supplementary Materials: The following are available online at https:/ / www.mdpi.com/article/10 .3390/plants10061190/s1, Figure S1: Dose-dependent effects of various concentrations of (A \& B) hot water extract of $A$. arabica bark, (C) peak samples, (D) Quercetin \& (E) Kaempferol at 5.6/16.7mM glucose on LDH release from BRIN-BD11 cells. 
Author Contributions: Conceptualization, P.A., P.R.F. and Y.H.A.A.-W.; formal analysis, P.A. and J.M.A.H.; investigation, P.R.F., P.A. and P.H.; methodology, P.A., P.H. and Y.H.A.A.-W.; resources, P.R.F., P.H. and Y.H.A.A.-W.; supervision, P.R.F. and Y.H.A.A.-W.; writing-original draft preparation, P.A.; writing - review and editing, P.A. and P.R.F. All authors have read and agreed to the published version of the manuscript.

Funding: There is no outsource of funding for this project.

Data Availability Statement: The data presented in this study are available on request from the corresponding author. The data are not publicly available due to restrictions.

Acknowledgments: We would like to thank Ulster University Strategic Research Funding and award of the Vice Chancellor's research studentship to P.A.

Conflicts of Interest: The authors declare that there is no duality of interest associated with this manuscript.

$\begin{array}{ll}\text { Abbreviations } \\ \text { AWERB } & \text { Animal Welfare and Ethical Review Board } \\ \text { HWAA } & \text { Hot-water extract of Acacia arabica } \\ \text { DM } & \text { Diabetes mellitus } \\ \text { T2DM } & \text { Type } 2 \text { diabetes mellitus } \\ \text { STZ } & \text { Streptozotocin } \\ \text { GLP-1 } & \text { Glucagon-like peptide-1 } \\ \text { GIP } & \text { Glucose-dependent insulinotropic polypeptide } \\ \text { DPP-IV } & \text { Dipeptidyl peptidase-IV } \\ \text { LDL } & \text { Low-density lipoprotein } \\ \text { HDL } & \text { High-density lipoprotein } \\ \text { HFF } & \text { High-fat fed } \\ \text { TG } & \text { Triglycerides } \\ \text { TFA } & \text { Trifluoroacetic acid } \\ \text { AMC } & \text { 7-amino-4-methylcoumarin } \\ \text { ANOVA } & \text { Analysis of variance } \\ \text { IBMX } & \text { Isobutylmethylxanthin }\end{array}$

\section{References}

1. American Diabetes Association. Diagnosis and Classification of Diabetes Mellitus. Diabetes Care 2008, 32, S62-S67. [CrossRef]

2. Ansari, P.; Flatt, P.R.; Harriott, P.; Abdel-Wahab, Y.H. Insulinotropic and antidiabetic properties of Eucalyptus citriodora leaves and isolation of bioactive phytomolecules. J. Pharm. Pharmacol. 2021, 23, 1-13. [CrossRef]

3. Mulla, C.M.; Baloch, H.M.; Hafida, S. Management of Diabetes in Patients Undergoing Bariatric Surgery. Curr. Diabetes Rep. 2019, 19, 112. [CrossRef] [PubMed]

4. Holst, J.J. From the Incretin Concept and the Discovery of GLP-1 to Today's Diabetes Therapy. Front. Endocrinol. 2019, 10, 260. [CrossRef] [PubMed]

5. Deacon, C.F. Physiology and Pharmacology of DPP-4 in Glucose Homeostasis and the Treatment of Type 2 Diabetes. Front. Endocrinol. 2019, 10, 80. [CrossRef]

6. Pan, S.-Y.; Litscher, G.; Gao, S.-H.; Zhou, S.-F.; Yu, Z.-L.; Chen, H.-Q.; Zhang, S.-F.; Tang, M.-K.; Sun, J.-N.; Ko, K.-M. Historical Perspective of Traditional Indigenous Medical Practices: The Current Renaissance and Conservation of Herbal Resources. Evidence-Based Complement. Altern. Med. 2014, 2014, 1-20. [CrossRef] [PubMed]

7. Pareek, H.; Sharma, S.; Khajja, B.S.; Jain, K.; Jain, G.C. Evaluation of hypoglycemic and anti-hyperglycemic potential of Tridax procumbens (Linn.). BMC Complement. Altern. Med. 2009, 9, 48. [CrossRef] [PubMed]

8. Patel, D.K.; Prasad, S.K.; Kumar, R.; Hemalatha, S. An overview on antidiabetic medicinal plants having insulin mimetic property. Asian Pac. J. Trop. Biomed. 2012, 2, 320-330. [CrossRef]

9. Singh, L.W. Traditional medicinal plants of Manipur as anti-diabetics. J. Med. Plant Res. 2011, 5, 677-687.

10. Balaraman, A.K.; Singh, J.; Dash, S.; Maity, T.K. Antihyperglycemic and hypolipidemic effects of Melothria maderaspatana and Coccinia indica in Streptozotocin induced diabetes in rats. Saudi Pharm. J. 2010, 18, 173-178. [CrossRef]

11. Bnouham, M.; Ziyyat, A.; Mekhfi, H.; Tahri, A.; Legssyer, A. Medicinal plants with potential antidiabetic activity-A review of ten years of herbal medicine research (1990-2000). Int. J. Diabetes Metab. 2006, 14, 1-25. [CrossRef]

12. Ansari, P.; Hannon-Fletcher, M.P.; Flatt, P.R.; Abdel-Wahab, Y.H.A. Effects of 22 traditional anti-diabetic medicinal plants on DPP-IV enzyme activity and glucose homeostasis in high-fat fed obese diabetic rats. Biosci. Rep. 2021, 41. [CrossRef] 
13. Singhal, R.; Agarwal, V.; Rastogi, P.; Khanna, R.; Tripathi, S. Efficacy of Acacia arabica gum as an adjunct to scaling and root planing in the treatment of chronic periodontitis: A randomized controlled clinical trial. Saudi Dent. J. 2018, 30, 53-62. [CrossRef]

14. Aro, A.; Uusitupa, M.; Voutilainen, E.; Hersio, K.; Korhonen, T.; Siitonen, O. Improved diabetic control and hypocholesterolaemic effect induced by long-term dietary supplementation with guar gum in type 2 (insulin-independent) diabetes. Diabetologia 1981, 21, 29-33. [CrossRef]

15. Wadood, A.; Wadood, N.; Shah, S. Effects of Acacia arabica and Caralluma edulis on blood glucose levels of normal and alloxan diabetic rabbits. J. Pak. Med. Assoc. 1989, 39, 208-212.

16. Asad, M.; Aslam, M.; Munir, T.A.; Nadeem, A. Effect of Acacia nilotica leaves extract on hyperglycaemia, lipid profile and platelet aggregation in streptozotocin induced diabetic rats. J. Ayub Med Coll. Abbottabad JAMC 2014, 23, 3-7.

17. Patil, R.N.; Patil, R.Y.; Ahirwar, D. Study of some medicinal plants for antidiabetic activity in alloxan induced diabetes. Pharmacologyonline 2010, 1, 53-60.

18. Patil, R.N.; Patil, R.Y.; Ahirwar, B.; Ahirwar, D. Evaluation of antidiabetic and related actions of some Indian medicinal plants in diabetic rats. Asian Pac. J. Trop. Med. 2011, 4, 20-23. [CrossRef]

19. Hegazy, G.; Alnoury, A.M.; Gad, G.H. The role of Acacia Arabica extract as an antidiabetic, antihyperlipidemic, and antioxidant in streptozotocin-induced diabetic rats. Saudi Med. J. 2013, 34, 727-733. [PubMed]

20. Wang, J.; Gao, H.; Zhao, J.; Wang, Q.; Zhou, L.; Han, J.; Yu, Z.; Yang, F. Preparative Separation of Phenolic Compounds from Halimodendron halodendron by High-Speed Counter-Current Chromatography. Molecules 2010, 15, 5998-6007. [CrossRef]

21. Selvaraj, K.; Chowdhury, R.; Bhattacharjee, C. Isolation and structural elucidation of flavonoids from aquatic fern Azolla microphylla and evaluation of free radical scavenging activity. Int. J. Pharm. Pharm. Sci. 2013, 5, 743-749.

22. Rather, L.J.; Islam, S.-U.; Mohammad, F. Acacia nilotica (L.): A review of its traditional uses, phytochemistry, and pharmacology. Sustain. Chem. Pharm. 2015, 2, 12-30. [CrossRef]

23. El-Aziz, A.; Awad, N.E.; Seida, A.A.; EL-Khayat, Z. Biological and chemical evaluation of the use of Acacia nilotica (L.) in the Egyptian traditional medicine. Int. Bull Drug Res. 2013, 3, 1-19.

24. Tanko, Y.; Abdulazeez, A.; Muhammad, A.; Jimoh, A.; Mohammed, K.A.; Mohammed, A. Effect of methanol crude leaves extract and aqueous fraction of Acacia nilotica on lipid profile and liver enzymes on alloxan-induced diabetic rats. Ann. Exp. Biol. 2014, 2, 36-40.

25. Pratt, E.P.S.; Harvey, K.E.; Salyer, A.E.; Hockerman, G.H. Regulation of cAMP accumulation and activity by distinct phosphodiesterase subtypes in INS-1 cells and human pancreatic $\beta$-cells. PLoS ONE 2019, 14, e0215188. [CrossRef]

26. DeFronzo, R.A. From the Triumvirate to the Ominous Octet: A New Paradigm for the Treatment of Type 2 Diabetes Mellitus. Diabetes 2009, 58, 773-795. [CrossRef] [PubMed]

27. Pessin, J.E.; Saltiel, A.R. Signaling pathways in insulin action: Molecular targets of insulin resistance. J. Clin. Investig. 2000, 106, 165-169. [CrossRef]

28. Fu, Q.-Y.; Li, Q.-S.; Lin, X.-M.; Qiao, R.-Y.; Yang, R.; Li, X.-M.; Dong, Z.-B.; Xiang, L.-P.; Zheng, X.-Q.; Lu, J.-L.; et al. Antidiabetic Effects of Tea. Molecules 2017, 22, 849. [CrossRef]

29. Saltiel, A.R.; Kahn, C.R. Insulin signalling and the regulation of glucose and lipid metabolism. Nat. Cell Biol. 2001, 414, 799-806. [CrossRef]

30. O'Harte, F.; Højrup, P.; Barnett, C.R.; Flatt, P.R. Identification of the site of glycation of human insulin. Peptides 1996, 17, 1323-1330. [CrossRef]

31. Abdel-Wahab, Y.; O'Harte, F.; Ratcliff, H.; McClenaghan, N.H.; Barnett, C.R.; Flatt, P.R. Glycation of Insulin in the Islets of Langerhans of Normal and Diabetic Animals. Diabetes 1996, 45, 1489-1496. [CrossRef] [PubMed]

32. Hunter, S.J.; Boyd, A.C.; O’Harte, F.; McKillop, A.M.; Wiggam, M.I.; Mooney, M.H.; McCluskey, J.T.; Lindsay, J.R.; Ennis, C.N.; Gamble, R.; et al. Demonstration of Glycated Insulin in Human Diabetic Plasma and Decreased Biological Activity Assessed by Euglycemic-Hyperinsulinemic Clamp Technique in Humans. Diabetes 2003, 52, 492-498. [CrossRef] [PubMed]

33. Rajvaidhya, S.; Singh, G.K.; Nagori, B.P.; Alok, S. Extraction, isolation and chemical structure elucidation of daidzein from bark of Acacia arabica (Lam.) Willd of Bhopal, Madhya Pradesh, India. Int. J. Pharm. Sci. Res. 2014, 5, 2014-2021. [CrossRef]

34. Jovanović, J.A.; Mihailović, M.; Uskoković, A.S.; Grdović, N.; Dinić, S.; Poznanović, G.; Mujić, I.; Vidaković, M. Evaluation of the Antioxidant and Antiglycation Effects of Lactarius deterrimus and Castanea sativa Extracts on Hepatorenal Injury in Streptozotocin-Induced Diabetic Rats. Front. Pharmacol. 2017, 8, 793. [CrossRef]

35. Proença, C.; Freitas, M.; Ribeiro, D.; Tomé, S.M.; Oliveira, E.F.T.; Viegas, M.F.; Araújo, A.N.; Ramos, M.J.; Silva, A.M.S.; Fernandes, P.A.; et al. Evaluation of a flavonoids library for inhibition of pancreatic $\alpha$-amylase towards a structure-activity relationship. J. Enzym. Inhib. Med. Chem. 2019, 34, 577-588. [CrossRef]

36. Rubanza, C.D.K.; Shem, M.N.; Bakengesa, S.S.; Ichinohe, T.; Fujihara, T. The content of protein, fibre and minerals of leaves of selected Acacia species indigenous to north-western Tanzania. Arch. Anim. Nutr. 2007, 61, 151-156. [CrossRef]

37. Edwards, C.; Blackburn, N.; Craigen, L.; Davison, P.; Tomlin, J.; Sugden, K.; Johnson, I.T.; Read, N.W. Viscosity of food gums determined in vitro related to their hypoglycemic actions. Am. J. Clin. Nutr. 1987, 46, 72-77. [CrossRef]

38. King, A.J.F. The use of animal models in diabetes research. Br. J. Pharmacol. 2012, 166, 877-894. [CrossRef]

39. Müller, T.; Finan, B.; Bloom, S.; D’Alessio, D.; Drucker, D.; Flatt, P.; Fritsche, A.; Gribble, F.; Grill, H.; Habener, J.; et al. Glucagon-like peptide 1 (GLP-1). Mol. Metab. 2019, 30, 72-130. [CrossRef]

40. Drucker, D.J. The role of gut hormones in glucose homeostasis. J. Clin. Investig. 2007, 117, 24-32. [CrossRef] 
41. Tanday, N.; Irwin, N.; Flatt, P.R.; Moffett, R.C. Dapagliflozin exerts positive effects on beta cells, decreases glucagon and does not alter beta- to alpha-cell transdifferentiation in mouse models of diabetes and insulin resistance. Biochem. Pharmacol. 2020, 177, 114009. [CrossRef]

42. Brunton, S. GLP-1 receptor agonists vs. DPP-4 inhibitors for type 2 diabetes: Is one approach more successful or preferable than the other? Int. J. Clin. Pract. 2014, 68, 557-567. [CrossRef]

43. Duffy, N.A.; Green, B.D.; Irwin, N.; Gault, V.A.; McKillop, A.M.; O’Harte, F.; Flatt, P.R. Effects of antidiabetic drugs on dipeptidyl peptidase IV activity: Nateglinide is an inhibitor of DPP IV and augments the antidiabetic activity of glucagon-like peptide-1. Eur. J. Pharmacol. 2007, 568, 278-286. [CrossRef]

44. Fan, J.; Johnson, M.H.; Lila, M.A.; Yousef, G.; De Mejia, E.G. Berry and Citrus Phenolic Compounds Inhibit Dipeptidyl Peptidase IV: Implications in Diabetes Management. Evid. Based Complement. Altern. Med. 2013, 2013, 1-13. [CrossRef]

45. Zhang, L.; Zhang, S.-T.; Yin, Y.-C.; Xing, S.; Li, W.-N.; Fu, X.-Q. Hypoglycemic effect and mechanism of isoquercitrin as an inhibitor of dipeptidyl peptidase-4 in type 2 diabetic mice. RSC Adv. 2018, 8, 14967-14974. [CrossRef]

46. Zu, Y.; Li, C.; Fu, Y.; Zhao, C. Simultaneous determination of catechin, rutin, quercetin kaempferol and isorhamnetin in the extract of sea buckthorn (Hippophae rhamnoides L.) leaves by RP-HPLC with DAD. J. Pharm. Biomed. Anal. 2006, 41, 714-719. [CrossRef] [PubMed]

47. Haselgrübler, R.; Stadlbauer, V.; Stübl, F.; Schwarzinger, B.; Rudzionyte, I.; Himmelsbach, M.; Iken, M.; Weghuber, J. Insulin Mimetic Properties of Extracts Prepared from Bellis perennis. Molecules 2018, 23, 2605. [CrossRef] [PubMed]

48. Hannan, J.; Ansari, P.; Haque, A.; Sanju, A.; Huzaifa, A.; Rahman, A.; Ghosh, A.; Azam, S. Nigella sativa stimulates insulin secretion from isolated rat islets and inhibits the digestion and absorption of $(\mathrm{CH} 2 \mathrm{O}) \mathrm{n}$ in the gut. Biosci. Rep. 2019, 39, 1-15. [CrossRef] [PubMed]

49. Ansari, P.; Flatt, P.R.; Harriott, P.; Abdel-Wahab, Y.H.A. Anti-hyperglycaemic and insulin-releasing effects of Camellia sinensis leaves and isolation and characterisation of active compounds. Br. J. Nutr. 2020, 1-15. [CrossRef]

50. Ansari, P.; Azam, S.; Hannan, J.; Flatt, P.R.; Wahab, Y.H.A. Anti-hyperglycaemic activity of H. rosa-sinensis leaves is partly mediated by inhibition of carbohydrate digestion and absorption, and enhancement of insulin secretion. J. Ethnopharmacol. 2020, 253, 112647. [CrossRef]

51. Hannan, J.M.A.; Ali, L.; Khaleque, J.; Akhter, M.; Flatt, P.R.; Abdel-Wahab, Y.H.A. Antihyperglycaemic activity of Asparagus racemosus roots is partly mediated by inhibition of carbohydrate digestion and absorption, and enhancement of cellular insulin action. Br. J. Nutr. 2011, 107, 1316-1323. [CrossRef] [PubMed]

52. Thomson, H.; Ojo, O.; Flatt, P.; Abdelwahab, Y. Antidiabetic actions of aqueous bark extract of Swertia chirayita on insulin secretion, cellular glucose uptake and protein glycation. J. Exp. Integr. Med. 2014, 4, 268. [CrossRef]

53. Kasabri, V.; Flatt, P.R.; Abdel-Wahab, Y.H.A. Terminalia bellirica stimulates the secretion and action of insulin and inhibits starch digestion and protein glycation in vitro. Br. J. Nutr. 2009, 103, 212-217. [CrossRef]

54. Gallagher, A.; Flatt, P.; Duffy, G.; Abdel-Wahab, Y. The effects of traditional antidiabetic plants on in vitro glucose diffusion. Nutr. Res. 2003, 23, 413-424. [CrossRef]

55. Flatt, P.R.; Bailey, C.J. Abnormal plasma glucose and insulin responses in heterozygous lean (ob/+) mice. Diabetologia 1981, 20, 573-577. [CrossRef] [PubMed]

56. Srinivasan, D.; Ojo, O.O.; Owolabi, B.O.; Conlon, J.M.; Flatt, P.R.; Abdel-Wahab, Y.H. The frog skin host-defense peptide CPF-SE1 improves glucose tolerance, insulin sensitivity and islet function and decreases plasma lipids in high-fat fed mice. Eur. J. Pharmacol. 2015, 764, 38-47. [CrossRef]

57. Kissoudi, M.; Sarakatsianos, I.; Samanidou, V. Isolation and purification of food-grade C-phycocyanin from Arthrospira platensis and its determination in confectionery by HPLC with diode array detection. J. Sep. Sci. 2018, 41, 975-981. [CrossRef]

58. Zhang, S.; Zhao, Y.; Ohland, C.; Jobin, C.; Sang, S. Microbiota facilitates the formation of the aminated metabolite of green tea polyphenol (-)-epigallocatechin-3-gallate which trap deleterious reactive endogenous metabolites. Free Radic. Biol. Med. 2019, 131, 332-344. [CrossRef]

59. Grace, M.; Warlick, C.W.; Neff, S.A.; Lila, M.A. Efficient preparative isolation and identification of walnut bioactive components using high-speed counter-current chromatography and LC-ESI-IT-TOF-MS. Food Chem. 2014, 158, 229-238. [CrossRef] 